Trinity University

Digital Commons @ Trinity

Religion Faculty Research

Religion Department

8-2008

\title{
The Design Argument in Classical Hindu Thought
}

C. Mackenzie Brown

Trinity University, mbrown@trinity.edu

Follow this and additional works at: https://digitalcommons.trinity.edu/relig_faculty

Part of the Religion Commons

Repository Citation

Brown, C. M. (2008). The design argument in classical Hindu thought. International Journal of Hindu Studies, 12, 103-151. doi: 10.1007/s11407-008-9058-8.

This Post-Print is brought to you for free and open access by the Religion Department at Digital Commons @ Trinity. It has been accepted for inclusion in Religion Faculty Research by an authorized administrator of Digital Commons@ Trinity. For more information, please contact jcostanz@trinity.edu. 


\section{THE DESIGN ARGUMENT IN CLASSICAL HINDU THOUGHT}

\section{BY C. MACKENZIE BROWN}

According to an influential early nineteenth-century British colonial historian and philosopher, the cosmogonic stories of a culture may be used to assess its progress towards civilization. This historianphilosopher, observing India from afar, ${ }^{1}$ warns us to be wary of any fantastical, irrational description of creation "if it includes not even a portion of that design and contrivance which appear in the ordinary works of man; if it carries the common analogies of production, in animal and vegetable life, to the production of the universe, we cannot be mistaken in ascribing it to a people, whose ideas of the Divine Being were groveling." Turning his attention to Hindu cosmogonic myths, the author asks: "what are the ideas which the Hindus have reached concerning the wisdom and beauty of the universe[?]" His answer is unambiguous: "No [literate] people, how rude and ignorant soever,...have ever drawn a more gross and disgusting picture of the universe than what is presented in the writings of the Hindus. In the conception of it no coherence, wisdom, or beauty, ever appears: all is disorder, caprice, passion, contest, portents, prodigies, violence, and deformity. It is perfectly evident that the Hindus never contemplated the universe as a connected and perfect system, governed by general laws, and directed to benevolent ends...." Thus did James Mill (1773-1836) in his The History of British India attempt to judge the progress of Hindu society at the beginning of British imperial rule in the Indian subcontinent, on the basis of the Hindus' supposed total ignorance of the concepts of divine design and the rational contrivance of the universe. ${ }^{2}$ Any refined notions of God's unity and wisdom, fundamental to western ideals of divine creation, he dismissed in the Hindu case as likely due to relatively recent and foreign influence, especially of Islam (Mill 1820, I:313-26).

Underlying Mill's antipathy to the Hindu accounts of creation was his objection to emanationist ideas of God transforming himself into the material world, thereby blurring the distinction between Creator and creature (see Mill 1820, I:335), coupled with an apprehension that unconstrained flights of imagination and the glorification of Eros would undermine the supremacy of reason (cf. Javed Majeed 1992, 183, 185). These concerns reflect and reinforce Mill's assumption of a created universe that is essentially mechanistic in nature - a critical presupposition of any design argument. The Hindu myths upon which Mill based his judgment, such as the cosmogony in Manu, were exuberant in their non-mechanistic, organic and 
protoplasmic imagery. Manu, for Mill, starts out promisingly enough with the "self-existing power" creating the primordial waters by a thought. But then Manu proceeds to talk about planting in the waters a fertile seed that becomes an egg from which the creator himself is born in the form of Brahma after more than a trillion and a half years, a ridiculous amount of time in Mill's view. Among other fantastic notions in Mill's estimation is the production of the four castes from Brahma's body parts, and still later the splitting of Brahma into male and female, as if “'The Mighty Power' could not produce [other creatures] by his male virtue alone...” (Mill 1820, I:289). In all these analogies of vegetative and animal reproduction, of sexual imagery and birth, the rationalistic and somewhat puritanical Mill saw at work only the fantastic, even licentious, imagination of a crude and effeminate mentality. Manu's account of cosmogenesis, in all its "vagueness and darkness, incoherence, inconsistency, and confusion," presents to Mill's eyes a stark contrast to Moses's description in Genesis, that with "a few strokes [attempts] to convey an idea of the magnitude of the task [of creation], and of the power and wisdom of him who performed it" (Mill 1820, I:286). Mill was apparently unaware of Hindu mythic accounts that emphasize more mechanistic models of creation that portray God as an architect or potter, as encountered in the Vedas and Upaniṣads, and that later inspired or complemented elaborate Hindu versions of the design argument.

Mill, at least during the time he wrote his History, was either unfamiliar with, or unswayed by, critiques of the design argument such as those offered by the Scottish philosopher David Hume. Hume directly challenged the mechanistic assumptions underlying much eighteenth-century western natural theology, invoking in the process various organic models of creation, including certain Hindu cosmogonic notions. He noted that "The Brahmins assert, that the world arose from an infinite spider, who spun this whole complicated mass from his bowels, and annihilates afterwards the whole or any part of it, by absorbing it again...." As ludicrous as such a model may have seemed to Europeans, Hume concludes, "Why an orderly system may not be spun from the belly as well as from the brain, it will be difficult...to give a satisfactory reason" (Hume 1964, 425).

The Baptist evangelical missionary William Ward, unlike Mill, spent many years in India, translating and interpreting with the help of pandits many Hindu Sanskrit works, including the philosophical treatises of the six "orthodox schools" of which Mill was largely ignorant. Ward took careful note of the various conflicting Hindu opinions about such questions as whether the world was created or 
had sprung into existence by itself - the variety of conflicting views confirming for the missionary the futility of human wisdom in the absence of revealed (biblical) truth. Of special interest in light of Mill's rational-design-critique of cultures, however, is Ward's discussion of the Hindu argument against the Buddhists, who "affirm, that the world sprung into existence of itself, and that there is no creator, since he is not discoverable by the senses." Ward then states: "Against this, the writers of the orthodox durshunus [darśanas] insist, that proof equal to that arising from the senses may be obtained from inference, from comparison, and from sounds. ${ }^{3}$ The following is one of their proofs from inference: God exists; this we infer from his works. The earth is the work of some one-man has not power to create it. It must therefore be the work of the being whom we call God" (Ward 1817-20, 2:117). This brief synopsis, covering both the design argument as well as the complementary cosmological argument for the existence of God, points to a vibrant, rational approach to theology that Mill did not believe Hindu thinkers were capable of when left to their own devices.

This essay examines three classical Hindu thinkers belonging to two of the so-called orthodox darśanas who address the question of design in the universe and its implications for theism. The first two, Śankara (c. 700-750 C.E.) and Udayana (c. 975-1050 .E.), advance elaborate articulations of the design argument against their non-theistic opponents. The third, Rāmānuja (fl. 1120 C.E.), while accepting the design argument in some contexts, vigorously rejects it in the main, putting forth counterarguments that anticipated Hume by some seven centuries. Thus, not only did Hindus have a fully developed natural theology, but they also were keenly aware of limitations and weaknesses of the design argument. Several aspects of the Indian classical debates have close parallels in the West, while others are particular to the Hindu context or to the special characteristics of a given school. And as in the West, traditional Hindu notions of an intelligent designer that were revived in the nineteenth century during British rule contributed to a cultural climate predisposed against full acceptance of a robust Darwinian evolutionary view of life.

Apparent design in the Advaita Vedānta of Śankara. Advaita Vedānta's most renowned classical exponent is famous for his characterization of ultimate reality, or Brahman, as the One absolute reality beyond all activity and transformation, and transcending all rational comprehension. Equally well known is Śankara's evaluation of this world as not fully real, even if not quite unreal. The perceived universe for him is a misleading realm of multiplicity whose true nature is obscured through the power of Māyā, the 
magical force behind the cosmic illusion. Anyone familiar only with these features of the Advaitic world view may be surprised to find Śankara using the methods of logic and inference to establish the existence of God (İ́vara) on the basis of the design argument. ${ }^{4}$

For Śankara, Brahman is both the material as well as efficient cause of the universe. He illustrates this dual causality by elaborating upon the famous metaphors in the Chāndogya Upanișad (6.1.4-5), likening Brahman to clay and gold as the material sources (prakrti, upaadāna-kärana) of earthen pots and gold ornaments, on the one hand, and to the potter and goldsmith as their efficient causes (nimitta-kärana), on the other (Vedānta Sütra Bhāṣya 1.4.23). Śankkara further entertains the notion that Brahman as material cause evolves out of itself the physical world, and provides the time-honored analogy, mentioned by Hume, of the spider emitting its threads (Vedānta Sūtra Bhāssya 1.4.26-27). But as Brahman is beyond all change or modification, the evolution (parināma) just spoken of is only a misleading appearance or manifestation of Brahman, and the seemingly evolved effects are only a matter of naming or labeling, for as effects they are not real in themselves. ${ }^{5}$ Brahman is thus likened to a magician (māy $\left.\bar{a} v \vec{\imath}\right)$ creating and maintaining the illusion of the world (Vedānta Sūtra Bhāṣya 2.1.1; 2.1.14).

It is this magical creative power of Māyā that allows Brahman, beyond all attributes (nirgụna), to manifest Itself with qualities (sagụna), such as creativity. In this way Brahman becomes known as İśvara, Lord, or creator of the world. While Brahman in Its Absolute Oneness is only to be known by a higher sort of realized knowledge, there is a lower knowledge appropriate to the mundane world. As Ninian Smart notes, from the higher level, this world is illusory, "but the empirical existence of the cosmos can be explained, as due to the creative activity of a Lord. Thus natural theology, inappropriate at the higher level, reappears at the lower" (Smart 1964, 100). We see now how Śankkara can provide a clear theistic argument for the existence of God (as İ́vara) based on design, even though the world is apparent only.

Śankara presents the design argument in his commentary on the Vedānta Sütras. In explaining the second sütra of Bādarāyaṇa's text (1.1.2), Śankara alludes to the main basis for the design argument, the wondrous arrangement of the world: "The creation, maintenance, and destruction of this worlddifferentiated by names and forms, serving as the platform for diverse agents and enjoyers to experience the fruits of action according to definite places, times, and causes, and having the nature of arrangement (racan $\bar{a})$ that transcends comprehension—are produced from the omniscient, omnipotent Brahman as their 
cause." While the precise nature of the world's arrangement, racanā, may be beyond rational comprehension, the notion that there is arrangement for Śankara is largely self-evident. ${ }^{7}$ The term racana itself basically refers to an arrangement or disposition of parts, and by extension to a contrivance. The passage also indicates that for Śankara the cosmic arrangement is teleological in a morally purposive way, as it encompasses the karmic or moral order as well as the physical order of the universe. ${ }^{8}$

Śankara proceeds to affirm, on the basis of scriptural authority, that the cause of the world is not a non-intelligent Primal Matter (Pradhāna), the view of the Sāmkhyan school of evolutionists (parināma$v \bar{a} d a)$. Nor can the cause of the world be atoms (anus) as the Vaiśeșikas or Atomists claim. Nor can it be attributed to transmigrating souls, nor to non-existence (śünyatā), the Buddhist view, nor to the inherent nature (svabhāva) of the world as the Materialists (Cārvākas or Lokāyatas) would have it. Rather, the cause must be something both omniscient and omnipotent, namely Brahman, as the Vedānta-texts proclaim (Vedānta Sūtra Bhāṣya 1.1.2). For Śankara, scripture is the primary means of knowledge regarding Brahman, since Brahman is not an external object knowable by perception or inference. But reasoning, so long as it does not contradict scripture, can be used to confirm the meaning of the text (Vedānta Sütra Bhāṣya 2.1.12-13) (cf. Francis X. Clooney 1993, 103-06).

After countering his opponents on the basis of scripture, Śankara turns to more purely rational arguments against them. ${ }^{9}$ We shall focus primarily on his refutation of the atheistic Sāmkhya, for it is in this context that he presents his design argument most forcefully. Śankara perceived a special need to counter the teachings of the Sāṃkya, for as he observes, the Vedānta Sütras "again and again call into question and refute the Sāmkhya doctrine of Primal Matter being the cause of the world, for it appears at first sight, to those of dull minds, that in the Upanișads are found some passages resembling and confirming that point of view. And by accepting the notion that cause and effect are non-different (käryakāranānanya), the Sāṃkhya comes close to the teachings of Vedānta" (Vedānta Sūtra Bhạsya 1.4.28). ${ }^{10}$ Śankara is confident that once the Sāmkhya doctrine is dispensed with, the other opposing theories like those of the Vaiśeșikas can easily be refuted by extending the same arguments.

The key sūtra of Bādarāyana, on which Śankkara commences his rational refutation of the Sāṃkhyā, reads literally and rather obscurely as follows: "And the inference, due to its failure regarding design, is not (valid)" (racanā-anupapatteśca nānumānam; Vedānta Sūtras 2.2.1). The inference, or thing inferred 
(anumāna), is the Pradhāna of the Sāṃkhya, and Bādarāyana's cryptically succinct statement points to the idea that Primal Matter cannot be the cause of the world, as a non-intelligent cause cannot account for the design $(r a c a n \bar{a})$ we see in the world. The specific type of inference (anumāna) leading to the notion of Pradhāna is based on an analogy (also referred to as anumāna). Accordingly, Śankkara begins his critique by summarizing the basic Sāṃkhya analogy from which is inferred the existence of an evolving but insentient Primal Matter: just as pots and dishes made of clay all have the common quality of their source, the clay, so also the diverse effects in this world, both inanimate and animate, have the common qualities of their source, pleasure $(s u k h a)$, pain $(d u h k h a)$, and dullness or delusion (moha) - that is, they all have the qualities of the three gụnas of Primal Matter — and thus Pradhāna must be their material source. Further, as Śankara continues with his summary, "like clay, the non-conscious Pradhāna, in order to facilitate the purpose of the conscious soul (cetanasya purusasyārtha), just by its own nature (svabhāva) begins transforming itself (vikārātmana pravartate) in various ways" (Vedānta Sütra Bhạsya 2.2.1).

Śankara seizes on the incompleteness of the clay analogy as presented by the Sāṃkhya and critiques their consequent misconstrual of the teleological argument. He argues:

If this issue [regarding the cause of the world] is to be resolved by force of analogy alone, then consider that in ordinary life no non-intelligent entity is observed to produce modifications suitable for satisfying the purposes of some particular person, by itself, without being superintended by an intelligent agent. In ordinary life what we do see is that houses, palaces, couches, seats, pleasuregardens and the like, which are useful for obtaining pleasure and avoiding pain at appropriate times, are constructed (racitā) by intelligent craftsmen. In like manner, observe that this entire universe, externally consisting of the earth and other elements, is suitable for experiencing the fruits of various acts; and with regard to the self, starting with its physical body whose various forms are fixed by birth and whose limbs (avayava) have a regular arrangement (vinyāsa), observe that such body is an abode (for the soul) to experience the fruits of diverse acts. Since even the most competent craftsmen cannot comprehend (the world's construction), how could the non-intelligent Material Nature (Pradhāna) devise (racayet) it? ${ }^{11}$ In the case of such things as a lump of earth or a stone, no (power of contrivance) is seen, but the design (racanā) of special forms out of such things as clay is seen when they are superintended by potters and the like. In the same way, Material Nature 
(transforms itself) only when connected with a superintending, external intelligence. And in ascertaining the essential nature of the root cause of the world, it is not appropriate to note only the material causality (upādana-svarūpa) of such things as clay while ignoring external agents like potters. It thus follows that there is some guiding ruler. Nor is this view at all inconsistent with, but rather it conforms to scripture which designates the cause as intelligent. Therefore, since the design of the world is otherwise inexplicable (racanā-anupapatti), its cause is not to be inferred as nonintelligent. $^{12}$

We may note the following three points regarding Śankara's argument above. First, rather than associating the beneficent ends found in the natural world directly with the benign intentions of a compassionate God—as a William Paley might do—Śankara links enjoyment to the realization of the fruits of one's action. In Śankara's view, the soul's ability to experience pain and pleasure depends upon the purposeful contrivance of both inanimate sense objects, as well as animate sensing bodies inhabited by the souls, as part of the moral plan and order of the universe. Sankara does not spell out the details of this psycho-physical contrivance, but his reference to earth and the other elements along with bodily parts (avayava $=\operatorname{limb}$, member, constituent element) is suggestive of the correspondence between the five physical elements and the five sense organs that form part of the evolutionary sequence in the Sāmkhya, and which Vedānta also accepts. Such marvelous ordered correspondence, from this perspective, is hardly due to chance. In sum, the nature of the samsaric realm of rebirth is so constructed as to allow for the reaping of karmic fruits, leading to the final end of liberation. Sankara uses the arrangement of parts and limbs in animate beings to indicate, not how well organisms are adapted to their environment for the purposes of survival, but rather to illustrate how well we are constructed to work out our karmic destinies.

Second, Śankkara refrains from detailed consideration of the specific features of order and contrivance allegedly found in the natural world, not just because he assumes these to be largely selfevident, but also because his opponent likewise accepts that the world exhibits evidence of purposive design. Like Śankkara, Sāṃkhya assumes a teleological perspective in assuming that the purpose of material evolution is to provide souls (purușas) with experiences of pleasure and pain leading eventually to liberation from the cycle of rebirth. But the purușas were not the contriver of the body or the world, for that was the work of Pradhāna or Prakṛti (Primoridal Nature). In the Sāṃkhya, then, we have an argument 
for design, but no intelligent designer. The Sāmkhya design argument is used rather to prove the existence of the soul that is the beneficiary of design. As Mysore Hiriyanna notes: "The Sāṃkhya concludes from the presence in nature of means adapted to the accomplishment of ends, not to God as their author, but to the self for whom it supposes them to exist. It thus accepts design, but denies a conscious designer" (Hiriyanna 1949, 124-25; cf. Smart 1964, 81). For Śankara, design not only points to a beneficiary, but also requires a benefactor, an intelligent İśvara. In terms of the basic analogy, the Sāṃkhya's sole focus on the clay and the pot while neglecting the potter, in Śankara's view, simply highlights the inadequacy of their position.

Third, we may recall that Î́vara for Śañkara is ultimately a great magician playing tricks for his own amusement, as it were, rather than being merely a highly skilled artisan. This accords with the real nature of Brahman, as It is complete and perfect, lacking nothing, and therefore can have no ulterior purposes to fulfill. Likewise, Brahman's manifestation as İ́sara ultimately has no purpose (artha), and thus Î́vara can have no purpose in producing the illusion of the world, other than as a kind of play or sport. The choice of a pleasure-garden (vihāra-bhuumi), in particular, to illustrate the kinds of contrivances that Brahman/İ́vara creates nicely suggests both the idea of the karmic enjoyment of the fruits of actions, and the notion of Brahman's contemplative recreation as the Self. The term vihära itself means sport or play as well as pleasure.

Śankkara's critique of the inadequate teleology of the Sāmkhya, that the unassisted Pradhāna cannot act with any purpose or future goal in mind, is somewhat ironic, given the Advaitic insistence that Brahman Itself has no purpose (prayojana) to fulfill. Śankkara anticipates just such an objection a few passages prior to presenting the design argument quoted above. After noting that Brahman is without motive or goal, having no unfulfilled desires (Vedānta Sütra Bhạsya 2.1.32), Śaṅkara continues: "Just as in common earthly life a king or his minister, with all desires fulfilled and without any goal (prayojana) or purpose (abhisamdhāya), may engage in sportive activities (līlā-rūpāh pravrittayah) amidst pleasure grounds (krị̂a $-v i h \bar{a} r a)$, and just as exhalation and inhalation transpire without reference to any external goal or purpose but by innate propensity (svabhāva) alone, in the same way the Lord, without reference to any other goal, by innate propensity alone, may engage in sportive activity" (Vedānta Sūtra Bhạssya 2.1.33). ${ }^{13}$ 
Such a view of İ́vara's sportful activity when applied to creation of the world lays him open to the charge of partiality and cruelty, for some beings are happy, some miserable, and others in between. But, Śankara insists, one cannot reproach the Lord for such apparent cruelty and malice, for He is merely following the constraints of karma - the merit and demerit of the sentient beings caught in the cycle of samsara (Vedānta Sūtra Bhạsya 2.1.34). While one might further ask if observing the constraints of karma does not restrict the freedom of the Lord, Sankara instead pursues the problem of how the initial inequalities in merit and demerit could have arisen. He concludes that, like the cycle of seed and sprout, the beginningless cycle of desires and actions leaves seeds for future desire in the soul (cf. B. N. K. Sharma 1986, 1:409). That is, the karmic cycle is beginningless, which is possible because the world also is without beginning. In this manner, the Lord is exonerated from any possible blame for the inequalities and miseries of the world (Vedānta Sütra Bhạsya 2.1.35-36). With this appeal to the inexorable working of karmic law, Śankara — like many Hindus - attempts to resolve one of the major challenges to theism, the problem of evil in a world supposedly created by a beneficent, or in Śankkara's case, a playful but not meanspirited, Lord.

The Advaitin, however, has an additional difficulty. Brahman can be charged not only with indifference or even sadistic impulses, but also with seemingly masochistic proclivities. For Brahman, being non-different from the Self, seems to create for Itself a prison of torture. As Śankara acknowledges on behalf of his opponents, if the Self is a free and independent agent (as Brahman is), then that Self "should create only what is beneficial (hita) for the Self, delighting the mind, and not what is detrimental such as the myriad assortments of senseless ills like birth, death, old age, and disease. For no person, not coerced by another, would make a prison for himself and then enter it. Nor would he, being perfectly stainless, acknowledge on his own this wholly unclean body as himself. Also, in every way he would abandon by his will whatever he has created that produces misery, appropriating for himself only the pleasant" (Vedānta Sūtra Bhạssya 2.1.21). Remembering surely that he has created the whole imaginary sphere of the world, would not the Self, like a magician, retract the illusion of this world which he has spread out, withdrawing it whenever he wished? But as the opponents observe, the embodied Self cannot reabsorb even its own body at will. 
Śankara's immediate response is to affirm, in a qualified way, the difference between the supreme Brahman and the embodied Self, but he still must contend with scriptural statements like "That you are" ("Tat tvam asi") which attest to the identity of the Self and Brahman. Sankara's resolution of the dilemma is to take refuge in the doctrine of the two levels of truth, mundane knowledge which is ultimately false, and the higher, realized level of ultimate truth: "When by means of the declaration of non-difference found in such passages as 'That you are,' the truth of non-difference (abheda) becomes realized, then the soul's transmigratory existence vanishes, as well as the creativeness of Brahman. For this whole pluralistic realm of worldly affairs, manifested through misapprehension (mithyā-jñanna), is dissipated by means of right knowledge (samyag-jñanna). Under those circumstances, what shall we make of creation? Or what shall we make of such faults as not doing what is beneficial?" (Vedānta Sūtra Bhāsya 2.1.22) With the creator reduced to the status of a conjurer and cosmic design to merely a mirage, theodicy becomes largely irrelevant, for suffering is summarily dismissed and seemingly not taken very seriously (cf. B. N. K. Sharma, 1986, 1:411).

Following his presentation of the design argument to counter the Sāṃkhya idea of a designing but non-intelligent Pradhāna, Śankara next turns to the complementary cosmological argument for the existence of God, looking to the original cause of the world - its prime mover-rather than to the intended end or purpose. For Śankkara, the Sāṃkhya's eternal but insentient Pradhāna along with its gunas are incapable of initiating motion in the universe after a period of dissolution, for this in his view would take an act of will. Among other reasons, if activity were an essential property of Pradhāna, then this Pradhāna should always be engaged in activity and its effects or productions ever manifest, in which case there is no way to explain the alternating creation and dissolution of the universe. However, the existence of an intelligent Lord, who is active at times and inactive at others according to his will, resolves the issue (Vedānta Sūtra Bhạsya 2.2.4). The notion that activity must be initiated by an intelligent, or at least living, being is a common assumption of non-materialist perspectives, as seen in the West in Plato's affirmation that when an entity "moves itself," it is "alive," and that the soul, whose defining characteristic is "selfmovement," "by her own motions stirs all things in sky, earth, or sea" (Plato 1961, 1451, 1452). ${ }^{14}$

Śankkara now takes up the refutation of the atheistic Vaiśeșika of Kanāada, author of the Vaiśeșika Sütras (ca. $3^{\text {rd }}-2^{\text {nd }}$ century B.C.E.) The later followers of Kaṇāda, as noted by Śankara, developed a theistic 
version of Vaiśeșika, as we shall see. Śankkara's key points against atheistic Vaiśeșika parallel his critique of the Sāṃkhya: just as the Sāṃkhya's eternal but insentient Pradhāna and its guṇas are incapable of initiating purposive motion in the universe after a period of dissolution, equally incompetent according to Śankara are the eternal but insentient atoms (paramānus) of the Vaiśeșikas. Let us then turn to the theistic Atomism of the Nyāya-Vaiśeșikas, and to the natural theology of Udayana in particular, which "represents the acme of perfection attained by the Nyāya-Vaiśeșikas in their rational search for God" and at the same time provides an overview of "Indian rational or natural theology in general" (George Chemparathy 1972, $8) .15$

Atomistic design in the Nyāya-Vaiśesika and the works of Udayana. The Nyāya and Vaiśeșika became associated with each other during the course of the first millennium C.E., and they shared a basic realist—as opposed to idealist or illusionist—outlook on the world (M. Hiriyanna 1932, 225). ${ }^{16}$ The Vaiśeșika, with its heavy reliance on empiricism and reason, readily espoused the logical methods and syllogistic refinements of the Nyāya in order to establish their point of view against all opponents, orthodox or otherwise. Both the Vaiśeșika, founded by Kaṇāda ( $3^{\text {rd }}-2^{\text {nd }}$ century B.C.E. $)$, and the Nyāya, founded by Gotama ( $3^{\text {rd }}$ century C.E.), were originally non-theistic, but difficulties in explaining certain aspects of the moral and physical order of the universe, such as those seized upon by Śankara, seem to have led later adherents of these systems to include God or İśvara in their cosmogonical deliberations. ${ }^{17}$ Once Î́vara was introduced into the Nyāya-Vaiśeșika view of the universe, then logical proofs for his existence were needed against non-theistic opponents.

Regarding the moral order of the universe, for Hindus in general the law of karma — the unseen force (adrsțta, apurva) constituting the merit and demerit of souls-is as much a law of nature as the law of gravity. A largely unresolved issue, however, is whether the karmic force, being unconscious, is selfoperative or requires a conscious, even all-knowing regulator of the moral law (Smart 1964, 152-53). Prior to Udayana, theistic Naiyāyikas like Vātsyāyana (ca. 425-500 CE) and Uddyotakara (fl. 600-650 CE) already argued that there must be an omniscient facilitator or dispenser of the fruits of karma to reconnect souls in the process of rebirth with their appropriate karmic load from their previous existences, since some sort of intelligent guiding principle is needed. The insentient $a d r s \underline{t} a$, lacking comprehension of any sort, let alone the knowledge to ascertain what merit and demerit belong to which individual souls, must be 
overseen by a directing intelligence. As Uddyotakara says in his Nyāya-Vārttika in arguing against the Sāmkhyans and the atheistic Atomists as well as the proponents of a self-acting adr̦șta force: "Primordial Matter (pradhāna), atoms (paramānus) and karma prior to the commencement of their own activity become active (only) when superintended by an intelligent cause, for they are without consciousness, like an axe and so forth. Just as axes become active (only) when overseen by a wood-cutter, since they lack consciousness, in the same matter Primordial Matter, atoms, and karma, lacking consciousness, become active (only when superintended by a conscious agent)" (Nyāya-Vārttika 4.1.21; p. 945). ${ }^{18}$ To the objection that some unconscious things can be active, as when insentient milk flows from a cow, Uddyotakara counters, "But not from a dead cow!" It flows only under the power of a conscious agent.

Uddyotakara goes on to say that the conscious agent directing the karmic process cannot be the ordinary soul, for a person (purusa), prior to attaining a body with its senses, is unconscious and unknowing, and thus incapable of connecting himself with his merit and demerit. So long as he is unconscious, until he receives a body and senses, there is no karmic efficacy, no activation of merit and demerit. From what or by whom are his merit and demerit, unperceived by the soul, reacquired? The only alternative, Uddyotakara clearly implies, is the Lord. Further, he says, a soul would not create misery for itself: "If a person (purusa) were acting freely (without the burden of karma), he would not engender (his own) suffering, for no one desires suffering for oneself' (Nyāya-Vārttika 4.1.21; p. 947). For Uddyotakara and the Nyāya-Vaiśeșikas in general, given that İ́vara and the ordinary souls are distinct, Śankara's dilemma of the masochistic Brahman/Self is easily avoided. The Lord merely oversees the karmic process, but is not responsible for the karmic deeds themselves that result in suffering.

Udayana largely assumes the necessity of an omniscient facilitator of karmic desserts, accepting the moral arguments for God mentioned above that had already been established by earlier Nyāya-Vaiśeșikas. By Udayana's time, although the reality of a transcendent moral order was regarded as largely self-evident among the major religious and philosophical thinkers, the lingering skepticism of the Cārvākas prompted repeated refutations of their amoral interpretation of the universe. Thus in his greatest work on natural theology, the Nyāya-Kusumāñali, Udayana devotes the first book or division to establishing the existence of the unseen, karmic force, as well as the existence of the immaterial soul. Udayana is confident that by establishing the reality of adrșta, the existence of God as the necessary facilitator of karma readily follows. 
This will become especially clear when we examine below the close interconnection between the moral or karmic arguments for God and Udayana's cosmological and teleological arguments. But before proceeding to Udayana's arguments for the existence of God, an overview of the Kusumāñjali will prove useful.

The Kusumāñjali is an independent treatise, not a commentary like Śankara's Vedānta Sūtra Bhạsya, and is thus free to follow purely logical or thematic considerations unconstrained by any order of sütras. It is a work devoted to proving the existence of God primarily through reason and logic, although with occasional reference to scriptural passages for the sake of additional confirmation, thereby differing from the Vedāntic approach that radically subordinates reason to scriptural authority. The full title of the work, Nyāya-Kusumāñjali, means literally "Offerings of Flowers consisting of Logical Arguments." These arguments intended to prove God's existence are thus represented as bouquets of flowers presented to his image, specifically to his feet (padayuge), ${ }^{19}$ alluding to the respectful gesture of cupped hands (añjali) with which such offerings are made (Karl H. Potter and Sibajiban Bhattacharya 1977, 558).

In the Kusumāñali there are five major divisions, or bouquets, offering various refutations of opposing viewpoints. Each of the five focuses, respectively, on specific objections to the notion of God. The first bouquet, as indicated above, deals with establishing the existence of the unseen force, in which Udayana refutes the claim that God does not exist because there is "no supernatural (alaukika) means for attaining the world beyond (heaven)" (Udayana 1996, 6). The remaining four bouquets contend with the objections that "there are other means (not dependent upon the existence of God) for attaining the world beyond, namely the performance of rituals; that there are valid means of proving that God does not exist; that even if God does exist, his knowledge is not reliable or valid; and that there is no conclusive proof (sädhaka-pramāna) that he does exist" (Udayana 6). In the course of his arguments, Udayana takes on the views of various schools, especially the Cārvākas, Sāṃkhyas, Mīmāṃsakas, Buddhists, and Jains. Interestingly, Udayana did not argue against the Vedāntins regarding the idea of God in the Kusumāñjali because, as Chemparathy notes, "these [Vedāntins]—even the Advaita Vedāntins—admit an Íśvara, though in a manner different from that taught in the Nyāya-Vaiśeșika school" (Chemparathy 1972, 31). ${ }^{20}$

Through the first four bouquets, Udayana often emphasizes that there are no rational arguments that disprove God's existence. Having established this negative claim, he concentrates in the fifth bouquet on 
the positive arguments for God's existence. Four of these shall occupy our attention: 1) the necessity for the world, as an effect, to have an intelligent cause; 2) the necessity for an intelligent prime mover given the inability of inert atoms to self-initiate motion and thus to form compound substances; 3) the necessity for the world to have an external supporting and destroying intelligent power; and 4) the need of humankind for an omniscient instructor of language, customs, and religious tutoring or revelation. ${ }^{21}$ Some of these proofs are more cosmological and causal, some more teleological, in their emphases, but as with Śankara all are inextricably intertwined. ${ }^{22}$ Several of Udayana's arguments closely parallel Śankkara's, sometimes with similar, sometimes with dissimilar justifications. ${ }^{23}$

Udayana's Kusumāñjali, incidentally, with its sophisticated and elaborate proofs for the existence of God, provides perhaps the clearest rebuttal to James Mill's verdict regarding the lack of natural theology in classical India. Even when Udayana's writings gradually came to be discovered, translated, and published by westerners in the middle of the nineteenth century, their assessments were slow to change. Edward B. Cowell, for instance, who translated and published sections of the Kusumāñjali in 1864, after noting that its logic and metaphysics were "unborrowed from any other land," belittled Udayana's efforts in this backhanded compliment: "it cannot be uninteresting to trace the brave efforts of a Hindu thinker, far away from the circle of Christianity, who, perplexed by the doubts or open disbelief taught in many of the systems current in his day, endeavoured, however vainly, to build for his countrymen the first truth of Theology on a firm logical foundation" $(1983, v) .{ }^{24}$ Cowell's appraisal represents a rather meager advance upon Mill's.

The world-as-effect argument. Udayana's first argument is that the "Earth and such things are attended (or preceded) by a creator (kartṛ), for they are effects (kārya)" (Udayana 1996, 369). In different words, the universe, having the nature of an effect as it is composed of parts, must have a composer. Udayana, in another of his works, the Kiraṇa $v a l i$, , elaborates upon the basic argument: "What comes into existence in the absence of an embodied being is dependent upon a prior intelligent causal agent, as it has the nature of possessing a cause. Whatever possesses a cause, like a chariot, is dependent upon a prior intelligent causal agent. Similar in character is this world; therefore it is dependent upon a prior intelligent causal agent. ${ }^{, 25}$ As Chemparathy explains, during the period of dissolution according to the NyāyaVaiśeșika, there are no embodied beings, so the creation of the world with its mountains and trees is 
independent of any embodied being $(1972,88)$. God is not embodied, but is intelligent. The maker of the universe must be omniscient and eternal, that is, God, for he alone passes through the cosmic dissolution with his consciousness unaffected and his knowledge of the fundamental structures of the universe and of karmic fruits intact. ${ }^{26}$

The argument in the Kiranāvali assumes that God is disembodied. In the Kusumāñjali, the basic challenge that Udayana takes on is whether or not an effect, like the universe, can only be produced by an embodied creator. Must the maker of the world be embodied, as perception would lead us to believe based on our normal experience of makers? The objection that there are no disembodied creators raises the possibility that the earth, like the ether, is not a product at all, not being produced by any embodied, intelligent agent (cf. Potter and Bhattacharya 1977, 581; Bhaswati Sinha 1999,, 241-42). Udayana develops a series of technical, logical arguments to refute the various objections based on the idea that a creator must be embodied. These counterarguments boil down to the idea that some things may require an embodied creator, but it is not proven that all things require such. Further, Udayana entertains the possibility that atoms may become the body of God, if the term body is taken to mean only the seat or substratum of actions, not the seat of sense-organs or of enjoyment. God's possessing a body in either of these last two senses would make his knowledge limited and dependent on information received through his senses, and would subject him to experiences of pain and pleasure.

The arguments for the disembodied creatorship of God in the Kusumañnjali are largely of a speculative, rational nature. Udayana presents more empirical arguments in his Atmatattvaviveka. There he refers, for instance, to the phenomenon of frogs (bhekas) found firmly encased within solid stones, and avers that it is impossible for even an invisible embodied being to create these frogs without breaking the stones - only a disembodied agent, God, can enter within the solid rock to carry out this somewhat odd creative act (Udayana 1995, 408-09). ${ }^{27}$ Udayana in the same passage also cites the ability of snakecharmers to remove poison from bitten persons simply through mental concentration, perhaps with God's auxiliary help, thus acting directly through mental effort rather than mediately through some secondary material body. Accordingly, while some agents with limited capacities (like most ordinary humans) require a body to be causally effective, there is nothing to rule out a bodiless agent if that agent possesses eternal cognition, eternal desire to act, and eternal effort. ${ }^{28}$ 
Another difficult and related question for Udayana and the Nyāya-Vaiśeșikas concerns the recurring issue of how spirit can interact with matter. Granting for the moment that a disembodied being can be causally effective, how exactly does pure spirit, devoid of material body, impel matter, whether atoms or more complex structures like the world? Śankkara simply asserts that Î́vara can create by mere intention, but how is this possible, especially if the world is more than a kind of magical illusion as in Śankara's Advaita? Needless to say, Udayana does not indicate the precise manner in which İśvara, by intention and effort alone, effectuates his disembodied impact on atoms or larger entities, involving as it does a Hindu version of the highly intractable mind/body or spirit/body problem. ${ }^{29}$ Udayana was aware of the problem as suggested by his attempt to offer a partial solution, discussed below, by providing an intermediate embodied agent whose task is to carry out the specific creation of the physical world with all its sentient beings on behalf of the disembodied God underlying the universe at large.

In his Kiranāâalī Udayana presents the cosmogonic account of Praśastapāda, an earlier NyāyaVaiśeșika thinker (ca. $6^{\text {th }}$ century C.E.), who proposes just such an intermediary, embodied creator between the Lord or God and secondary creation. Praśastapāda, in his Padārthadharmasangraha, in explaining the means or method of creation and destruction of the four great elements (earth, water, fire, and air), declares that at the end of a cosmic cycle, the Great Lord (Maheśvara), in order to give rest to all creatures, brings to an end the operations of the unseen force of karma of all souls, disassociates those souls from the senses and gross elements that constitute their bodies, and then breaks up the gross elements into their constituent atoms. Only the ultimate or subtle atoms (paramānus) then remain, along with the souls and their (inactivated) karmic tendencies. When it is time for a new cosmic cycle to commence, the desire to create arises in Maheśvara in order to provide beings with further karmic experiences. This desire in turnsomehow-activates the invisible force of merit and demerit, which then propels the atoms to form dyads, assisted by Maheśvara's cognition of their proper form. First the gross element of air forms, then water, which forms a great oceanic mass. This is followed by the formation of earth and then fire. Once all the four gross elements are created, then Maheśvara molds fire and earth into a great egg — somehow—-through mere meditation or thought (abhidhyāna), as in Manu's cosmogony. From that egg are born manifold worlds and the assistant creator Brahmā, who is assigned the task of producing living beings. After 
producing various other progenitors, Brahmā finally produces from his head and limbs the four classes of society (Praśastapāda 1984, 48-49). ${ }^{30}$

Praśastapāda, followed by Udayana, seems indirectly to acknowledge the spirit/body problem in recognizing the possible need for an embodied creator, in the activity of Brahmā, while retaining the Lord's ultimate and purely immaterial oversight role. As Chemparathy comments on Praśastapāda's and Udayana's cosmogony: "Īśvara makes use of him [Brahmā] for the sake of effects which are known necessarily to require a bodied agent. In this interpretation the incorporality [sic] (aśarīratvam) of İ́vara is clearly safeguarded and an explanation is found for those activities of İ́vara which would necessarily require a body, since these are performed by Brahmā who possesses a body" (Chemparathy 1972, 146-47). Chemparathy goes on to note that Udayana "accepted that İ́vara can, on certain occasions and for specific purposes, take up a body" $(1972,147)$, but it is also clear that Udayana assumed that God could create without a body, although he provides no full explanation of exactly how that can be. In Praśastapāda's cosmogony, the means by which God's desire activates the unseen force which is thereby enabled to conjoin atoms in their appropriate forms is not clarified, and the spirit/body problem is thus left unresolved.

Praśastapāda, I may note incidentally, clearly attempted to give a philosophical interpretation to the older mythological cosmogonic motifs as found in Manu, which James Mill had found so problematic because of its chaotic complexity and fantastic organic imagery. Mill, we may recall, did approve of Manu's notion that the "self-existing power" created the primordial waters, or oceanic mass, by mere thought, but then Mill rejected as fantastic and savage Manu's description of subsequent phases of creation. Manu's initial stage of creation by will alone appeared acceptable to Mill as it correlates well with the Genesis account of creation. Yet Genesis provides no better explanation as to how God, as pure spirit, effects the movement of matter than Udayana. Nor, of course, does Genesis explain how God created matter in the first place, a notion quite perplexing to most Hindus, who insist upon the eternity of matter.

While much of the discussion of the world-as-effect (käryatva) argument deals with the gross, perceptible world, Udayana interweaves examples and considerations from the atomic level of reality. For instance, in response to the general objection that no one has perceived the creation of effects by disembodied creators, Udayana points out that just as different kinds of seeds produce different kinds of sprouts, so do different kinds of atoms produce different kinds of gross substances even though no one has 
seen this happen. Nor has anyone seen eternal qualities - such as color inhering in certain kinds of the most subtle atoms - produce color in gross atomic structures, yet who could deny that such processes happen? Otherwise, the orderly creation of gross objects from subtle atoms would be purely accidental (äkasmika) (Udayana 1996, 370). Thus, lack of direct experience of a disembodied creator, like the nonperception of atomic processes, is not a valid objection against God's creation of the world.

Underlying Udayana's atomic design argument is the classical Vaiśeșika atomic theory. According to this theory, the initial combination of subtle atoms (paramanus) resulting in the gross elements that we perceive as earth, water, fire, and air, proceeds in three basic stages. First, two atoms of the same type, for instance two earth atoms, must combine to form a dyad (dvyanuka). Then, three dyads all of the same type must combine to form triads (tryanuka) that constitute the first measurable or gross substances with their specific sensible qualities: earth with its smell, water with its taste, fire with its color, and air with its touch. (The fifth element "ether" is not atomic but all-pervasive, and thus cannot be combined; it serves as the substratum for sound.) Finally, these triads are used to create the various large bodies we see in the universe. If in stage one or two, unlike atoms or dyads were brought together, they would be unable to manifest definite qualities, like color and taste, and thus would fail to serve the purpose of providing pleasurable and painful experiences to souls (see Bhattacharyya 1961, 125-26).

For Udayana, then, an intelligent agent is needed to bring about the proper, rather than random, combinations of atoms in order to subserve both cosmogonic and thus karmic purposes. The underlying assumptions in such a view are that all causal agents must be able to perceive the material substances they are to manipulate, as well as to possess the desire and will to create, like a potter who must be able to perceive the clay and also have the desire to create his products. ${ }^{31}$ Since atoms lack such perceptive ability as well as desire and will, any innate capacity such as inherent forces-chemical forces we would say today - to bring about by non-intentional means the products we see in the universe is simply not admitted. We see here a Hindu version of the (Strong) Anthropic Principle: the fine tuning of the atomic triads to allow for sentient experience suggests that someone knew we were coming.

Another objection raised against the Nyāya-Vaiśeșika notion of God's initiating creation is that since no one was present at that time, the conclusion that the universe is an effect caused by an intelligent agent is based only on dogmatic assumption (Bhattacharyya 1961, 79). This objection is reminiscent of certain 
Christian creationist arguments against evolution - that no one observed the ancient transformation of species - but here it is used against the theistic position. A contemporary of Udayana and fellow NyāyaVaiśeșika, Śrīdhara, responds to this objection in circular fashion: "If we set ourselves to analyse the nature of the earth, its contingent character is sure to arrest our attention. Consequently it becomes an effect like the jar though its actual creation may not have been witnessed by us" (trans. and quoted by Bhattacharyya 1961, 80). However compelling or otherwise Śrīdhara's argument, it is interesting that this NyāyaVaiśeșika theist has great confidence in the ability of inference to find a way of getting around the fact that "no one was there"- a claim of course central to Darwinian evolution and modern scientific explanations for the beginning of the universe. In other words, the lack of an original human witness can cut both ways: the Big Bang or the origins of life cannot be vouched for by direct and immediate human perception, but neither can God's creative act.

The incapacity-of-inert-atoms argument. In many ways Udayana's discussion or the world-as-effect argument for the existence of God anticipates and overlaps with his second argument regarding the causal force behind the initial instigation of atomic motion. Udayana begins his second argument, summarized by the word ayojana (joining or motion), in the following words: "If (atoms were) self-moving, they would not be insentient; the unseen force does not (by itself) bring about the visible world; in the absence of cause there will be absence of effect; the special characteristics (of gross elements) require specific characteristics (in the subtle causes or atoms)" (Udayana 1996, 401). Udayana proceeds in a manner reminiscent of Uddyotakara: "Atoms and the like commence motion only when a conscious being causes them to unite, for they are unconscious, like an axe and so on" (Udayana 401). ${ }^{32}$ Underlying Udayana's second argument is the fundamental assumption, shared in large part with Śankara as well as with Uddyotakara, that any entity capable of self-motion must be a sentient being. In different words, all movement requires volitional activity, as matter in itself-including atoms-is inert. ${ }^{33}$

As an historical aside, I note that both Śankara and Udayana join with the Catholic mechanistic philosopher of the early seventeenth century, Pierre Gassendi, in the view that atomism alone, without an overseeing God who imparts the special initial motions to the atoms, cannot account for their interactions. In Gassendi's case, his argument involved a Christianizing modification of Epicurean atomism, according to which infinite numbers of eternal atoms, falling "downward" through space in parallel paths, would 
occasionally and spontaneously swerve from their paths, initiating a cascade of interactive collisions. ${ }^{34}$ Gassendi introduced into the system the notion of God both as creator of the atoms, and as the necessary impeller of those atoms, causing them to swerve from their parallel paths, thereby imparting the motion to them that would eventuate in their forming larger wholes according to God's divine plan. In the process, Gassendi revived an early Christian tradition of the design argument, and influenced the English natural theologians of the seventeenth and eighteenth centuries (Richard G. Olson 2004, 77-78). These English natural theologies, or course, were to be imported into India in the nineteenth century, where they were to interact with the indigenous versions of the design argument. Needless to say, the question of the eternity of atoms or their created nature was a significant philosophical issue. For the Epicurean and the Indian traditions as represented by Udayana, the atoms were uncreated.

Udayana is aware of and attempts to justify the general Nyāya-Vaiśeșika assumption that all motion requires a sentient cause. He raises the possible objection that only certain kinds of movements require a sentient overseer, namely bodily, but atoms, not connected with a body and not directly overseen by a soul or mind, may be self-moving. Udayana's response is that there are, indeed, different kinds of movements: some are the result of direct supervision of a mind acting through a body, but other movements are brought about by effort and volition alone, without a body, and such is the movement of atoms overseen by a disembodied God (Udayana 1996, 402-403).

The maintenance-and-destruction argument. Let us now turn to Udayana's third argument: the world's need for an external supporting and destroying intelligent cause. ${ }^{35}$ I shall begin with the inference from support or maintenance. Udayana argues that the existence of God can also be inferred "Because of support (dhrti): for the whole universe, from the earth to (all the worlds contained in) the Egg of Brahmā, although heavy, does not fall, being supported by the volitional effort of some upholding agent, either directly in person, or by a sequence (of intermediate causes)" (Udayana 1996, 403)." In illustration of the direct and indirect means of support, he cites the example of a bird flying in the sky, its body supported directly by the bird, while something carried in its claws is indirectly supported. The role of the unseen force of adrșta in maintaining the universe, incidentally, is not discounted in this scenario, but is only seen as a partial or secondary cause still requiring a conscious agent to direct it. Here, as on other occasions, Udayana indicates that his conclusion through inference is supported also by scripture. In this instance, 
Udayana cites passages from the Bhagavad-Gìtā and the Upanișads simply to confirm his point, mentioning specifically the famous dialogue between Gārgī and Yājñavalkya in which the universe is seen as woven in the Imperishable Brahman, by whose command the earth and heavens are kept separate (Bṛhadāraṇyaka Upanișad 3.8.9) (Udayana 1996, 403; cf. Chemparathy 1972, 93).

Gopikamohan Bhattacharyya interprets Udayana's reference to the whole universe from the earth to Brahmāṇḍa (Brahmā’s Egg) as indicating stars ("luminaries") and planets, and regards Udayana's statement that they do not fall as referring to their respective orbits that keep them from colliding with each other (Bhattacharyya 1961, 131). While it is not unreasonable to see Udayana's reference to the many worlds contained in the Brahmāṇ̦a as referring to stars and planets, it is a bit of a stretch to read ideas of celestial and planetary orbits into Udayana. Rather, the plain sense of Udayana's statement reflects an intuitive folk physics that all things fall downward, unless obstructed, towards some ultimate lowest ground. ${ }^{36}$ Just as the bird's burden would fall to the earth without the conscious effort of the bird, so the earth would fall down (towards the unspecified but intuitively imagined lowest ground) without the conscious lifting action of a volitional agent, namely God. Such a notion seems incommensurable with the idea of orbits that keep planets not so much from falling as colliding, and certainly goes against the modern scientific notion that there is no absolute up-ness or down-ness in the universe. ${ }^{37}$

Interestingly, and in conformity with the Hindu notion of the three intrinsic and ever-cycling phases of the cosmos, Udayana regards dissolution, as well as creation and maintenance, as needing divine guidance. This point is succinctly suggested in the basic definition of his third argument: "On account of support and so forth (dhrtyādeh)," the "so forth" referring to the last of the three cosmic phases (Udayana 1996, 369). For Udayana, the dissolution of the universe even down to the deconstruction of the atomic dyads is said to require the same sort of conscious will, effort, and action as their combination. Thus, following his inference from the support of the universe, Udayana proceeds to discuss the implications of the destruction (samharana) of the universe in parallel fashion. The existence of God can be inferred, he says, "On account of destruction: for the whole universe from the Egg of Brahmā to the atomic dyads, being liable to destruction, is destroyed by an agent endowed with volitional effort" (Udayana 1996, 403). Udayana's illustration in this case is that of a piece of cloth being torn asunder, the analogy being that the universe, like cloth, does not unravel by itself. But why does the Lord will such cosmic dissolution? The 
destruction of the universe is not due to any malicious intent on the part of the Lord. As Surendranath Dasgupta notes, the Nyāya-Vaiśeșika in general attributes the dissolution of the universe to the desire of Íśvara to give all sentient beings a respite $(1963,323){ }^{38}$

Reflections on the first three arguments. All of Udayana's arguments that we have considered up to this point appeal more or less directly to the notion of order and arrangement in the physical universe that is produced by a benign being having our karmic interests in mind. The force of all these arguments, of course, rests in large part on the strength of the analogy that the natural world is very much like a human artifact or contrivance. Major attacks were made on the assumption that the artifact analogy was sufficiently appropriate or cogent to make the desired inference to God as the creator of the world a valid and compelling conclusion. Bhattacharyya nicely summarizes a Buddhist critique of this assumption:

It is a fact that if in a dense forest a dilapidated temple or an unused well is discovered, we are led to infer that they were the works of some intelligent author in some remote past. Here the particular arrangement of parts...which we observe in the temple or in the well proves an intelligent author. But the Buddhist here turns round to say that the illustration cited above does not justify the position of the Naiyāyika for, unlike the well or the temple, the hill, the sea and such other objects do not appear to possess particular conjunction of parts which will lead us to infer the existence of an intelligent designer. The arrangement of parts which we observe in the well, the jar etc. essentially differs from the arrangement of parts which we observe in a mountain. (Bhattacharyya 1961, 51)

The Buddhist concedes that mountains and the like are made up of parts, but ordinary experience does not detect in them the sort of systematic adaptation of parts we recognize in wells and temples (Bhattacharyya 1961, 52). The Buddhist, like Paley, thus makes a sharp distinction between artificial objects that give clear evidence of the contrivance of parts, and natural objects like a rock or mountain (over against a watch in Paley's case, or a pot or piece of cloth in the Nyāya-Vaiśeșika case), whose parts exhibit no obvious signs of mechanical design.

The Nyāya-Vaiśeșika response to the problematic nature of the artisan analogy is relatively unconcerned with examining any empirical details regarding the intricate arrangement of parts in the natural world, largely assuming that the universe as a whole does in fact exhibit order. Rather than trying to establish that there is design in the world, Nyāya-Vaiśeșikas rely instead on the larger moralistic world 
view based on karmic retribution and rehabilitation — a view that was shared by most of their non-theistic opponents, including the Buddhists. One Nyāya-Vaiśeșika response to the Buddhist counterargument challenging the analogy, for instance, begins by arguing that individual souls do not have the necessary knowledge or intelligence to design and put together mountains and oceans; only a supreme intelligence can do so. But the Buddhists counter that we have no evidence that there is an intelligent agent beyond individual souls, especially one that is omniscient, and thus the very entity in question is still far from proven. The Nyāya-Vaiśeșika response to such critiques, while often detailed and highly technical, inevitably returns to the moral, teleological argument. Thus, the Nyāya-Vaiśeșika argues that just as an axe is wielded by an intelligent being for felling trees that results in the benefit or suffering of different individuals, so also the mountains and seas produce pleasure and pain, and therefore like the axe must be under some intelligent supervision (Bhattacharyya 1961, 56-57). It is not their contrived design (which is far from apparent in the case of mountains and seas), but their alleged role in the karmic process that is important.

The Jains also raised similar objections regarding the applicability of the artisan analogy. As Bhattacharyya notes: "the Jaina makes out that the perception of the jar points to an intelligent jar-maker, whereas when we perceive the universe as a whole no idea of any creator flashes in our minds. Inference of intelligence from order and adjustment is available in the case of the jar and not of the world" (Bhattacharyya 1961, 71). The Jains like the Buddhists thus distinguish between two types of effects, those intelligently caused and those not so caused. A further Jain example is that of wild paddy growing far beyond human habitation, which we recognize grows without intelligent supervision, versus rice grown in prepared fields (Bhattacharyya 1961, 72, 74).

Various anti-theistic opponents pointed in comparable fashion to the sprouting of seeds in general, which seems to occur without being preceded or caused by any intelligent agent. The Nyāya-Vaiśeșika replies that actually all entities in the universe are created by God, some directly or absolutely, others indirectly. Pots and cloth are divinely created indirectly with humans acting as a co-creator. The sprouting of seeds, however, is not dependent on human activity, but only on God. In support of this argument, Surendranath Dasgupta points out that "if the objector could distinctly prove that there was no invisible maker shaping these shoots, then only could he point to it as a case of contradiction" $(1963,326)$. 
But then is God's creativity simply being equated with natural processes? For Udayana, the answer is no, for natural processes by themselves would tend towards chaos. As Dravid summarizes Udayana's argument: "The hand of God does not appear to be involved in the natural processes resulting in natural productions. Yet the constructive direction which the natural processes take because of which the world goes on evolving despite the prevalence of the destructive activity of human and non-human agents cannot be accounted for without the assumption of God's overall supervision of it" (Dravid 1996, 395). Here we see an interesting parallel to the contemporary creationist argument against evolution on the grounds that such a natural process overall violates the second law of thermodynamics - natural processes left on their own lead to disorder and chaos.

Two additional objections to the Nyāya-Vaiśeșika design argument, already encountered with Śankara, may be mentioned at this point. The first of these is the old but sturdy atheistic standby, the problem of evil, which is closely intertwined in the Hindu case with the second problem, the matter of God's motivation. A point of vulnerability seen by opponents in the pervasive teleological perspective of Udayana's arguments is the notion that God has created for some purpose. But this raises the question as to how he can have a purpose if he is complete and eternally satisfied in himself (or else he would not be God). Udayana's basic answer is that God does not create for himself, but out of compassion for others. But then, if this is so, why does he create a world so full of pain? The Nyāya-Vaiśeșika response to this further objection is that God creates the world not for the sake of the immediate happiness of creatures, but so they can grow spiritually, by experiencing the fruits of their positive and negative karma, and eventually liberation (Chemparathy 1972, 158-59). Thus is countered in standard Hindu fashion one of the major universal objections to the design argument, that the actual world with all its misery could not be the creation of a beneficent and all-powerful God. ${ }^{39}$

Interestingly, the Nyāya-Vaiśeșika largely avoids Śankara's "sportive impulse" resolution to the problem of God's motivation, for despite its intuitive appeal in a Hindu context, there are significant problems with this solution, as Śankara realized. The Jains, for instance, objected that such a view turns God into a whimsical child who plays without any purpose whatsoever, or else he is guilty of extreme favoritism. Uddyotakara refused the "sportive impulse" explanation, for even sport suggests that God is trying to find relief from some sort of misery (Bhattacharyya p. 141). For Udayana, however, as 
Chemparathy points out, while the notion of play does not have a significant role in Udayana, it is not altogether absent. Chemparathy notes two instances where Udayana refers to Íśvara's cosmic activities as his play, and to his "enjoying in sport at this own will" (Chemparathy 1972, 162). But since Udayana specifically rejects the idea that Î́vara would be acting to avoid suffering, or to gain something for himself that is not already in his nature, Chemparathy interprets Udayana's meaning as implying only that God creates spontaneously and with ease.

The tutorial design argument. The fourth and final argument of Udayana that we shall discuss may be termed the tutorial design argument, or alternatively, the cultural design argument. The basic idea is that all human language, customs, arts and crafts could not be discovered by human beings on their own, but require that such "usages" (pada) be taught to humankind by a divine and omniscient tutor at the beginning of each cosmic cycle. As Udayana states the argument, the existence of God can be inferred "On account of usages, for the skill of artisans such as weavers in manufacturing cloth, the (clear) use of language on the part of articulate speakers, the writing of letters of the alphabet in order on the part of young children, all these go back to a (knowing) being who is himself independent (untaught)" (Udayana 1996, 409). In earlier parts of the Kusumāñjali, in his arguments against the Mīmāṃsakas (to be discussed below), Udayana applies the notion of the necessity of a divine tutor to the teachings of the Veda. Just as human beings have forgotten language usage, arts, and crafts, so have they failed to recall the Vedic scriptures, until reminded by God at the beginning of a new cycle.

This general viewpoint makes sense in a culture which assumes that its form and organization have not gradually evolved but were fully established at the beginning of time (or at the beginning of the present cycle of creation). Further, this viewpoint rests on the assumption that knowledge is not something discovered but rather recovered, or revealed more or less in its entirety at one time. Knowledge is thus not something gradually attained over many generations, but is awakened to relatively quickly, as in childhood, with the proper instruction. Just as there must be a prime mover, so must there be a prime tutor. This approach to knowledge is augmented by an unquestioning respect for the wisdom of the ancients, and readily extended to the allegedly wisest and most ancient one of all: God who is eternal. Such assumptions, with their negative assessment of human ability for cumulative discovery extended over several centuries 
or millennia, was to emerge in the nineteenth and twentieth centuries in various negative Hindu responses to Darwinism.

One major counterargument to Udayana's cultural design argument came from the Mīmāṃsakas, the school of Vedic exegesis. We may note that at certain periods in their development the Mīmāṃsakas were considered akin to the Materialists due to their empirical orientation towards the everyday world, their naturalistic tendencies regarding the self-sufficiency of the material elements continually to transform themselves into the ordered world we perceive, and their general denial of God, or at least non-affirmation of God (Hiriyanna 1949, 135, 208 n6; Hiriyanna 1932, 324). However, they accepted the authoritativeness of the Vedas, in particular their ritualistic portions. Their non-theistic stance might seem to pose a problem for the sacred authoritativeness of the Vedas. But the Mīmāmsakas viewed the Vedas as without any authorship, being in themselves eternal, and thus not composed or revealed by any God. They are passed down from eternity within a beginningless chain of teachers and students. In addition, unlike most of the other orthodox Hindu schools, but like the Jains, they rejected the cyclic view of the universe, arguing instead for its eternality. Just as day follows the preceding day, infinitely, there is no first day of creation. To be sure, the Mīmāmsakas accepted that there might be general periods of development and decline within parts of the whole, but there was no total dissolution of the universe, and thus no need for complete re-creation, and no interruption in the transmission of the teaching. As Bhattacharyya notes, "The Mīmāmsaka posits that the world with its ramification is in existence at all times of creation and there has not been a point of time when the order of the universe, as it exists to-day, was not in existence" (Bhattacharyya 1961, 29). The view that the world, including its present order, is essentially eternal completely undercuts any sort of design argument, with its assumption that the world is an effect produced at some relatively specific point in time.

The lack of cosmic dissolutions also undercuts the argument for God from tutorial necessity. Without universal dissolution, there is no need of a cultural and religious revival at the beginning of a world cycle, no need for the re-creation of, or re-instruction in, Vedic ritual performances, language, arts and crafts. Bhattacharyya makes clear the conclusion with reference to the Vedic scriptures: “....as in the opinion of the Mīmāmssaka there is no cessation of the entire universe, the traditional cultivation and knowledge of the Vedic lore continues unimpeded and this continuity is preserved by the activities of 
teachers and the taught" (Bhattacharyya 1961, 29; cf. Chemparathy 1972, 96, 149). Bhattacharyya points out that the Mīmāmsaka accepts the idea of "day-to-day evolution" and acknowledges as constant the "process of becoming and passing away" (Bhattacaryya 1961, 30; cf. Chemparathy 1972, 94), and thus they are open to a God who oversees these relatively minor developments, but the potential damage to the design argument, and to theism in general, is clear. ${ }^{40}$

Udayana's response to the Mīmāṃsaka denial of a robust cosmic cycle begins by arguing for the possibility of periodic re-creation. ${ }^{41}$ For instance, just as a rainy day may follow a non-rainy day, as at the beginning of the monsoon season, so may a first day follow a period of destruction (Udayana 1996, 180). The main thrust of Udayana's response concerns the Mīmāmsaka claim that there are no complete dissolutions of the universe as a whole. Surveying the state of society and culture in his time, including the current state of Vedic learning, Udayana concludes that there has been a clear and observable degeneration of moral aptitudes, spiritual practices, and religious discipline compared to earlier periods, going back to the beginning of the present cycle. Among his evidences, he cites the degeneration in the mode of procreation through the ages, a deterioration in education, in spiritual knowledge, in human capacity, in the study of the Vedas, in the performance of religious rituals, and in intellect, resulting in the loss of transmission of the sacred traditions. Extension of these negative trends forwards points to a future time of complete moral degradation, while looking back in time points to a specific beginning when the world and human culture were created, or re-created, fresh and pristine.

In summing up, Udayana utilizes the classic metaphor of the dharma-cow, who in the first of the four ages, in the ideal Kṛta or Golden age, walks on four legs (austerity, knowledge, sacrifice, and charity), but who loses the use of a leg in each of the succeeding ages. In the current Kali Yuga, the cow has only the leg of charity to stand on, and even this leg is faltering as its foot is covered with the sores of ill-gotten moneys, stained with the filth of unbelief, and stung with the barbs of greed and anger (Udayana 1996, 189). ${ }^{42}$ Such degeneration occurring successively in each of the four ages or Yugas, in Udayana's view, will inevitably result in the radical loss of all culture and all Vedic learning at the end of the present cycle. For culture in general and Vedic learning in particular to persist continuously through time, they must be given a jump start at the beginning of every new cosmic regeneration, or else they would long ago have ceased to exist. Since no sentient beings, other than God, are available after the period of complete 
destruction, only God is capable of re-establishing the teachings. He is, in effect, the author of the Vedasand they are not eternal as the Mīmāṃsakas claim (Chemparathy 1972, 150).

The Mīmāmsakas at this point make a further counterargument: that while there may be a local decline of culture on Earth, it does not affect the cosmic order as a whole. Thus, when the Earth is in a state of severe decline the Vedic knowledge continues unabated elsewhere in the universe. Anticipating certain contemporary pseudo-scientific and New Age ideas, the Mīmāṃsakas then propose that teachers from other planets come to Earth to instruct men in religious duties. Udayana will have none of such sophistry, arguing that it is difficult enough to travel from one earthly continent to another, and that journeying to or from other worlds is impossible. He dismisses any supernatural means for cosmic travel, such as making oneself the size of an atom or as large as the universe, asserting that these are fanciful guesses. The simplest solution to the problem of Vedic regeneration, for Udayana, is that any "visit" from another world by a being of supernatural power is merely the manifestation of the omniscient and omnipotent God on Earth to instruct human beings at the beginning of a renewed cycle (Udayana 1996, 194; cf. Chemparathy 1972, 151).

One of the most sustained challenges to the Nyāya-Vaiśeșika design argument is that of Rāmānuja. One of his major objections, as we shall see, focuses on the inability of the design argument to establish just a single creative Lord. In this regard it is worth noting that Udayana largely ignores the question of possible multiple Lords. Like most natural theologians, Udayana is concerned not just with establishing the creative and other cosmic roles of the Lord, but also with demonstrating, at least indirectly, his natural attributes. Prominent among these, for Udayana, are the Lord's eternal cognition, will, effort, and beneficence (Chemparathy 1972, 164-79). But Udayana does not explicitly broach the issue of God's unity or oneness. As Chemparathy explains, the question of the number of Gods was a subject of much discussion in early Nyāya-Vaiśeșika theism among such exponents as Praśastapāda and Uddyotakara, who all argued that the Lord is just one. ${ }^{43}$ Udayana seems simply to have assumed Íśvara to be one only, as a necessary implication of his arguments for the existence of God. Thus, no separate treatment of God's oneness was necessary (Chemparathy 1972, 179-80). Rāmānuja seized upon this lack, apparently regarding it as a fatal flaw in the Nyāya-Vaiśeșika arguments, noting in addition other problems with the basic design analogy. 
Design discounted in the Viśiștādvaita of Rāmānuja. It is ironic that a non-dualist, Śankara, commends the design argument, while a theist, Rāmānuja, dismisses it. While Śankkara clearly subordinates rational and logical arguments for the existence of God to scriptural statement or śruti, so long as such rational arguments do not contradict scripture, he gives them a degree of plausibility, as in his design argument against the Sāṃkhya. Rāmānuja seems much more insistent that Brahman/God is to be known only from scripture. Knowledge of Brahman allows us to know the world, but observing the world, or its arrangement and order, does not lead us to any knowledge of Brahman, in his view. However, while he insists that perception, inferences from observed phenomena, and logical argument are incompetent means for knowing Brahman, he is not entirely averse to an occasional, tactical use of the design argument when dealing with non-theistic opponents. Nonetheless, unlike Śañkara, Rāmānuja offers a detailed critique of the design argument, thereby highlighting its logical limitations.

Rāmānuja's tactical use of the design argument. Rāmānuja's objections to the design argument are given in his commentary on the Vedānta Sütras, the Śrī Bhāşya. There are a few passages in the Śri Bhăsya, however, that give a qualified and minimal support to the design argument. We may recall that the second aphorism (Vedānta Sütras 1.1.2) refers to "Brahman as that from which this (world) arises." We have seen that Śankara, in commenting on this verse, refers to the incomprehensible arrangement of the world (acintya-racanā), which serves as a theater for karmic fulfillment. In like manner, commenting on the same aphorism, Rāmānuja notes the diverse and wonderful arrangements of the world that are not to be comprehended by thought (acintya-vividha-vicitra-racanā). Like Śankara, Rāmānuja further notes that all sentient beings experience here in the universe the fruits of their actions according to appropriate times and places, suggesting that the wonderful arrangements of the universe manifest an underlying moral order. The major difference from Śankara at this point is Rāmānuja's reference to the source of the world as the "Supreme Person" (para pums), endowed with such auspicious qualities as knowledge and bliss, who is supremely compassionate, and who is to be identified with Brahman, thereby emphasizing a theistic approach to the ultimate.

A more extensive elaboration of the design argument occurs in Rāmānuja's commentary on Vedānta Sütras 2.2.1 and following. It is these same aphorisms that inspired Śankara to articulate most clearly his own design argument, and we find that Rāmānuja closely follows the Advaitin's refutation of the atheistic 
Sāṃkhyan dualism at several points. Like Śankkara, Rāmānuja notes the misleading similarity of the Sāmkhya to Vedānta regarding the notion that effects pre-exist in their cause (satkārya-vāda). As for the three basic means of knowledge (pramānas), Rāmānuja agrees with the Sāṃkhya regarding matters provable by perception, while rejecting their view that scriptural authority confirms their overall nontheistic position, an erroneous view Rāmānuja has already dealt with in the first Adhyāya or division of the Vedānta Sütras. So Rāmānuja focuses here on the third pramāna, inference. If he can overturn the Sāmphya inferential arguments for their denial of God, then their whole position stands refuted. In summarizing the basic Sāṃkhya view, he notes in the same manner as Śankara the crucial inferential analogy: just as Primal Matter alone, consisting of the three gunas of pleasure, pain, and dullness, gives rise to the world consisting of those same qualities, so also clay and gold give rise to jars and gold ornaments. Rāmānuja rejects this analogy in the following manner:

The Pradhāna you Sāmkhyas affirm is not competent to produce the arrangement (racanāa) of this variegated world, for it is non-intelligent and not superintended by an agent understanding its essential nature. And so it is in similar situations, just as wood and other materials by themselves are incompetent to construct a chariot or palace and so forth. From observation we know that unconscious materials like wood that are not superintended by an agent who knows their nature fail to bring about effects, and also from observation we know that materials produce effects when supervised by a knowledgeable agent. Thus the Pradhāna unsupervised by a knowledgeable agent cannot be the cause (of the world). (Śrī Bhāṣya 2.2.1)

In Śrī Bhāṣya 2.2.3, Rāmānuja argues, again like Śañkara, that if the Pradhāna is not guided by an intelligent Lord, then creation would always exist and there could be no cosmic dissolution (pralaya), and thus a Lord whose purposes are ever realized is necessary to explain the alternating creation and dissolution of the universe. To the possible objections that such a superintending Lord, if fully perfect, cannot have the desire to create or destroy the universe, and if despite this he does create the universe with all its inequities, then he is without mercy (nirdaya), Rāmānuja responds in a standard traditional manner: even a perfect being may, for the sake of play (līlärtha), commence creative activity, and the inequalities in the world are simply due to the good and evil deeds of beings. ${ }^{44}$ This raises the possible counterargument that karma, in conjunction with Prakrti, is sufficient in itself to create the inequalities in the universe without requiring a 
superintending Lord. Rāmānuja replies that such a view exhibits a complete ignorance of scripture, which is the sole means of knowing about merit and demerit. Scripture, the eternal and faultless Veda, defines good and evil deeds as actions pleasing or not pleasing to the Supreme Person (parama purușa), and which result in pleasure or pain through the Lord's favor or punishment. Here we see Rāmānuja departing from purely rational argumentation, falling back on scripture at a critical juncture. We have here yet another indication that Rāmānuja's view of the deficient nature of reason lies behind his ultimate rejection of the design argument.

In his comments on the next several aphorisms (Vedānta Sūtras 2.2.4-9), Rāmānuja repeats several more of Śankkara's arguments against the Sāṃkhya. Rāmānuja concludes, however, by maintaining that these arguments militate not only against the Sāṃkhya, but also against those (like Śañkara) who uphold an unchanging Brahman that, by cognizing ignorance (avidya $)$, supposedly experiences an unreal bondage and an equally unreal liberation. For how can an unchanging Brahman come to be deluded? Rāmānuja states his preference at this point for the Sāṃkhya view, which despite its rejection of God at least admits a plurality of souls that accounts for the various births and deaths of different beings. The Advaitin idea that there is only one soul or self, as well as the idea that the illusory world can be an object of perception by an unchanging soul, for Rāmānuja constitute merely far-fetched imaginings (Śrī Bhāṣya 2.2.9).

Rāmānuja and Śankara both utilize the design argument for the purpose of negative demonstration (refutation of the Sāmkhya and other non-theistic positions), and both ultimately dismiss such arguments as inconclusive, but for quite different reasons. For Śankkara, all such proofs and their subject matter belong to the lower and illusory realm of mundane reality and ordinary knowledge. Rāmānuja rejects the idea that there are two levels of knowledge, equally with the notion of the illusory nature of the world. Thus it is not the idea that the apparent design in the world is only an illusion that causes Rāmānuja to reject the design argument, but rather that the argument is fraught with logical limitations, its fundamental analogies being weak and inconclusive, and its theological implications disastrous.

Rāmānuja's refutation of the design argument. Rāmānuja provides a detailed rebuttal of the design argument in addressing the issue as to whether knowledge of Brahman can be obtained from perception or inference, or only from scripture, the topic of the third aphorism in the Vedānta Sütras (1.1.3). ${ }^{45}$ In his comment on Vedānta Sūtras 1.1.3, Rāmānuja quickly dismisses perception as a valid means of knowing 
Brahman, since Brahman is not an object of sense. It is not knowable even through the subtle perception of the yogic, intuitive kind, as this latter merely reproduces things previously perceived in the normal way. The remainder of Rāmānuja's lengthy comment on Vedānta Sütras 1.1.3 is taken up with proving the inadequacy of inference, and in particular the failure of the argument from design in proving the existence of God.

Rāmānuja's critique begins with a summary statement of the design argument, presenting the view of his opponent who, though unnamed, often represents the standpoint of a theistic Nyāya-Vaiśeșika. As in most Hindu presentations of the design argument, the strictly teleological aspects that are presented are intertwined with cosmological considerations. According to the opponent's argument as summarized by Rāmānuja, the inference to God or a Supreme Being (Purușa) as an intelligent designer capable of knowing the entire realm of existent objects and of constructing the universe is based on the characteristic of the world being an effect. For we invariably find that effects are produced by competent agents knowledgeable about: 1) the material cause (upādāna), 2) the instrumental means (upakarana), 3) the recipient to be benefited (sampradāna), and 4) the purpose (prayojana). This is exemplified by the familiar case of effects like jars. Further, a non-intelligent (acetana) organic body, consisting of parts and thus an effect, is invariably controlled by a single intelligent being (eka-cetana), as illustrated by the example of one's own healthy body being ruled by a single intelligent controller.

The ensuing response to the opponent on the part of Rāmānuja centers largely on the question of whether or not reason can establish that God alone possesses such types of facilitating knowledge listed above, and that he alone has the capacity to construct and guide the non-intelligent universe. Since Rāmānuja, at least some of the time, accepts, like his opponent, that many important aspects of the universe manifest signs of design and other qualities that require an intelligent, active agent, or agents, to explain, his critique focuses on the supposed appropriateness and validity of the analogy between human producers and one Supreme Creator. A few arguments are also directed at the problem of whether inanimate entities like mountains and animate entities like organic bodies are really analogous to human artifacts. We shall proceed by looking first at these latter arguments, before turning to the more complex arguments regarding the analogy between human artificers and one universal creator. 
To the opponent's claim that an intelligent creator is proven by the fact that an organic body consists of integrated parts or limbs, Rāmānuja retorts that the intimate connection of parts (samavāya) needed to keep a body together requires only a particular conjunction of parts, not an intelligent principle that so orders them. He does not deny the intimate connection or inseparable inherence that the Nyāya-Vaiśeșika insist is intrinsic to an organic body as a whole in relation to its parts, but simply argues that such combination of parts may be brought about by non-intelligent means. For Rāmānuja, the special inherence of the parts in the whole is said to have other possible explanations, although he does not offer any explicit alternative.

Turning from living organisms to such grand and inanimate features of the natural world as mountains, oceans, and the earth as a whole, Rāmānuja argues that inference cannot establish that these are effects or artifacts produced by an intelligent being. What we actually observe in life is that an effect can be shown to have an intelligent causal agent (abhijña-kartrka) only when the material and other causal factors are known, and only when the effect can actually be reproduced, as is the case with jars and water pots. But in the case of large-scale objects like the earth, oceans, and mountains, knowledge of their material and other causes is not possible, according to Rāmānuja, and they cannot be reproduced, so no conscious creator (cetana-kartrka) can be proven. Further, even if one acceded to the argument above that organic bodies require a guiding intelligent principle for their integration, such bodies differ in a critical way from the earth, oceans, and mountains, for the latter do not breathe.

Regarding the problematic nature of the analogy between human agents and one supreme creator God, Rāmānuja offers three basic critiques regarding: 1) whether it can be established by reason that the intelligent cause is one and not many, 2) whether an intelligent cause must be embodied or not, and 3) whether the analogy regarding the implied similarity of God's nature and human nature is degrading to the character of the divine Being.

Inference from everyday experience to establish the supposed necessity of a solitary prime mover, as argued or assumed by both Śankkara and Udayana, is highly problematic for Rāmānuja. While the setting into motion (pravrtti) of any inanimate object may be dependent upon an animate being, it may equally be dependent upon many such beings, as in the case of moving heavy objects like chariots, large rocks, and trees. With regards to the universe, both Rāmānuja and his opponents agree that a creator competent to 
produce a given effect must have sufficient knowledge of the material, instrumental, and final causes as well as the capacity to produce the effect in question. The competence of the creator must be inferred from the nature of the object produced, and the more complex the product, the greater must be the knowledge and proficiency of its creative agent. According to Rāmānuja's presentation of his opponent's view, only some special being (purușa), the Lord, and no ordinary soul possesses such competence. As he summarizes the opponent's conclusion:

It is clear that ordinary souls with their limited powers and knowledge, and being under the control of their good and evil acts, lack competence for constructing such entities as organic bodies and the universe with their remarkable arrangement (samniveśa) of various parts. One may therefore infer that a special being, the Lord who is endowed with superhuman, incomprehensible, unlimited powers and knowledge, and who possesses the skill necessary to construct the entire universe, although he is bodiless, by mere volition has fully effected the wonderful arrangement (racanā) of the visible universe infinite in extent." (Śrī Bhāṣya 1.1.3)

We shall return to the matter of the Lord's bodiless, purely volitional creative activity in a moment, but first we must look at Rāmānuja's critique of the opponent's discounting of the capacity of "ordinary souls."

Rāmānuja makes two points: on the one hand, he argues that intelligent agents do not have to be omniscient. ${ }^{46}$ All that is required is merely sufficient knowledge, that is, immediate perception (sākșātkāra) of the relevant material causes such as earth and of the appropriate instrumental causes that are endowed with power (śakti), just as potters commence making pots having direct knowledge only of the clay and their implements, the wheel and molding sticks and the like, without bothering with all the inherent powers in those items. Thus, nothing prevents such agents from constructing the world. On the other hand, to the possible objection that investigation reveals the inability of souls to see very subtle, obscure, and remote entities as would be required of a world creator, Rāmānuja claims: "The conclusion that there is just one supreme causal agent surpassing all ordinary souls cannot be justified on the grounds that the latter lack the capacity for constructing this wonderful world, which is produced by some agent. For we can see the surprising powers of those exceptional souls abounding in accumulated merit who, by their capacity arising from their superior karma, are able to produce extraordinary effects - thus the idea that there is just one supreme person of infinite superior karma is faulty" (Śrī Bhāṣya 1.1.3). 
Another argument Rāmānuja offers for the possibility of multiple creators is that we have no evidence that the earth and the oceans were created — or will be destroyed —all at one time. The universe is not like a single jar that is created more or less in a single burst of activity. Rather, the universe consists of multiple effects. So there may be multiple creators, and multiple destroyers, just as we see in the work-aday world with its multiple products: things created at different times often have different producers. Experience simply does not point to a single agent capable of creating and later destroying everything at once. Rāmānuja concludes: "Both perception (pratyakșa) and inference (anumāna) go against the line of argument attempting to show that there is just one causal agent" (Śrī Bhāssya 1.1.3).

Having established in his own mind that reason by itself cannot demonstrate the oneness of the creative principle, Rāmānuja turns to his second major critique of the design argument, the old problem of whether or not a creative agent—single or otherwise - must be embodied. If the opponent wishes to argue that the Supreme Lord can create by mere volition alone, Rāmānuja counters that we do not actually observe such disembodied creators: "We see that potters and the like by means of their bodies wield their sticks, wheels, and so forth. So one cannot conclude that a disembodied Lord can wield the material and instrumental causes for producing the world" (Śrī Bhāsya 1.1.3). If the opponent further replies that there are instances of producing material effects by volition alone, as we see in the driving out of demons, ghosts, and venom from bodies by mere will power, Rāmānuja simply questions whether that is actually possible. In addition, he argues that there is no evidence to suggest that will power alone (or the mind, manas, that wills,), even if it exists eternally and independently as the Nyāya-Vaiśeșika claim, can produce any effects unless and until it is associated with a body.

Of course, it might be argued that God has a body. Rāmānuja considers two possibilities in this case: that God is permanently embodied, or only intermittently so. In the former case, then something made of parts, as bodies are, can be eternal. But then one may as well accept that the world with all its various parts is also eternal, and thus the assumption of a Lord who assembles the parts is unnecessary. In the latter case, how can one account for an occasionally existing body of the Lord, that is, for its irregular or spontaneous creation and destruction? For at the time when the Lord is without a body, there is no other body available to him. The possible objection that the Lord himself is the cause of his own body is problematic, for as already shown—in Rāmānuja's view—a disembodied being cannot by mere volition 
produce anything. Nor can he attain a body by assuming the body of someone else, for then we would have an endless regression of such body-borrowing without ever explaining how the body was created in the first place. Rāmānuja's rejection here of the idea that God has a body may at first seem to contradict his renowned soul-body model of God's relation to the universe, but his point is simply that on the basis of inference alone, there are irresolvable logical dilemmas.

Rāmānuja's third major critique of the design argument concerns the negative theological implications of the basic analogy between the causal agents. The stronger one makes the analogy between human creators and God, Rāmānuja protests, then the more disparaging of God the design argument as a whole becomes. ${ }^{47}$ For it is quite irreverent to suppose that the Lord, who has no aims, could share the same sort of qualities and limited capacities as humans, who are subject to karma and desire, and possess purposes based on those desires. While Rāmānuja elsewhere makes clear that he subscribes to the notion of $l \bar{l} l \bar{a}$ as God's "motivating force," based on experience cannot establish the existence of a non-motivated causal agent. As Rāmānuja states it, after concluding that scripture is the only valid means (pramanna) of knowing about the Lord: "Scripture declares that God is an ocean of infinitely great and immeasurably glorious virtues such as omniscience and unfailing resolution; he is utterly the opposite of all that is offensive, and radically different from all entities known by the other pramānas" (Śrī Bhāṣya 1.1.3).

Rāmānuja's thorough-going distrust of human reason and experience as a means of knowledge about God seems to be only part of his motive for discounting the design argument. A more fundamental if less self-conscious motivation may be an underlying antipathy to a mechanistic view of God's interaction with the world. We noted earlier Rāmānuja's soul-body model of God's relation to the universe. In his apparent rejection of the idea that God has an eternal body outlined above, Rāmānuja's thrust is that reason is helpless to show that the world itself, consisting of parts, could not be eternal, and therefore not in need of being assembled by a designing intelligence. But if the world (including souls) is eternal, as Rāmānuja ultimately holds, then God could have an eternal body consisting of that world — a notion he also embraces. We have here, then, a more organic than mechanistic view of reality. As Hiriyanna notes, for Rāmānuja "God is the immanent principle of Prakrti as well as of individual souls. The exact significance of representing them as his body is that they are sustained by him, are altogether subject to his control and 
entirely subserve his purposes....In other words, God together with the souls and matter is an organic whole" $(1949,181)$. Such an organic relationship, of course, establishes an intimate relationship between God and the individual soul or devotee appropriate to Rāmānuja's emphasis on bhakti.

We referred above to James Mill's dismissal of the ancient Hindu organic models of the universe as fantastic and absurd products of savage minds. Of course, the ancient mythological cosmogonies of any religious tradition are likely to strike a modern observer as "primitive" and unsophisticated, if not downright absurd, depending on the empathy of the observer. Later theological systems often represent, in part, a more reflective elaboration of motifs and themes, however crudely expressed, found in the original myths of a tradition. Rāmānuja's elaboration of the organic, soul-body model of the universe reflects a subtle and sophisticated theological understanding of reality that exhibits as much rational plausibility as more mechanistic models. His organic model is far from the absurd imaginings of untutored minds as claimed by James Mill. A brief comparison of Rāmānuja's refutation of the design argument with David Hume's nicely illustrates the point, as Hume can hardly be considered "an untutored mind."

Comparison of Hume and Rāmānuja. Hume is often regarded in the West as the thinker most responsible for refuting the design argument once and for all. His extended critique, most fully presented in his Dialogues Concerning Natural Religion published three years after his death, of course did not prevent others from continuing to espouse and elaborate upon the traditional design argument, as evidenced by Paley's Natural Theology (1802) and the Bridgewater Treatises (1833-1840), followed more recently by late twentieth-century versions such as the various elaborations of the (Strong) Anthropic Principle and most famously the notions of Intelligent Design. Rāmānuja, like Hume, failed to dissuade later proponents of the design argument within his own tradition, so great is the intuitive appeal of the argument even in widely differing cultural contexts.

Both Rāmānuja and Hume focus on weaknesses in the logic and experiential basis of the fundamental analogy underlying the design argument, and then proceed to draw out its unwelcome theological implications. Both recognize that the strength of the argument depends upon the degree of similarity of effects, that is, human artifacts and the universe, on the one hand, and similarity of causal agents, human artificers and God, on the other. As Hume's skeptical protagonist Philo declares in the Dialogues to his opponent, the design-advocating Cleanthes: "Now it is certain, that the liker the effects 
are, which are seen, and the liker the causes, which are inferred, the stronger is the argument. Every departure on either side diminishes the probability, and renders the experiment [theological inference] less conclusive" $(1964,411)$.

Rāmānuja, as we have seen, points out that jars and water pots are not like immense objects such as the earth, oceans, and mountains, whose material and other causes are simply not known. Further, these objects differ radically from organic bodies not only in size, but also in the fact that the former do not breathe. Finally, only when an effect can actually be reproduced by an artificer can we demonstrate that it must have an intelligent cause. Hume's Philo makes the same basic points. After noting the increasing dissimilarity, and thus the weaker and more imperfect analogy, between humans, frogs, and plants with regard to circulation of some vital fluid, blood or sap, respectively, he points out the even greater disparity between a house and the universe: "If we see a house, Cleanthes, we conclude, with the greatest certainty, that it had an architect or builder, because that is precisely that species of effect, which we have experienced to proceed from that species of cause. But surely you will not affirm, that the universe bears such a resemblance to a house, that we can with the same certainty infer a similar cause, or that the analogy is here entire and perfect" $(1964,393)$. Philo concludes that due to the striking dissimilarity of the effects, any inferences regarding similarity of causes are at best conjectures and guesses.

Turning to dissimilarity of causes, both Rāmānuja and Hume assume that observation can reveal something about human agency, but observation or experience can tell us very little about the nature of God. A priori approaches to God, such as abstract reasoning, or sound piety, or scripture, may tell us that God exists and that his nature is infinitely perfect, although beyond human comprehension. But $a$ posteriori approaches, such as the design argument, being based on experience and observation, can never reach to that divine mystery. In fact, for both Hume and Rāmānuja, any attempt to extend ideas about the workings and processes observed in the physical world to that which infinitely transcends that world is inevitably degrading to the infinite. Rāmānuja, we may recall, asserts that God's infinite greatness and goodness, known through scripture, are utterly opposed to all that is offensive, including many human qualities such as desire. In similar vein, Philo declares: "I was from the beginning scandalized, I must own, with this resemblance, which is asserted, between the Deity and human creatures; and must conceive it to imply such a degradation of the Supreme Being as no sound Theist could endure" $(1964,395)$. After 
pointing out the constant change in human passions and thoughts, Philo concludes: "How is this compatible, with that perfect immutability and simplicity, which all true Theists ascribe to the Deity?" $(1964,406)$.

A major dissimilarity in the causal agents is the oneness of God-almost uniformly asserted by proponents of the design argument—and the observed plurality of human agents. For Rāmānuja, experience shows that multiple human agents often work together to create a complex product, that they do not have to be all-knowing but only sufficiently competent in their particular craft, and that artifacts created at different times often have different producers, especially telling since there is no observable evidence that the universe was created all at one time. Inferences from what is observed thus suggest that the universe may easily have had multiple intelligent designers. Further, the special knowledge and insight necessary to create the complex and vast universe may well be within the competency of advanced souls of superior karma - an idea that resonates to some degree with the contemporary notion offered, rather defensively, by supporters of Intelligent Design that the designed creation of this world and its life forms may be due to aliens from another world and not to a single Supreme Being. As for Hume, multiple gods or demons may play the role of aliens or advanced souls. In the mouth of Philo:

A great number of men join in building a house or ship, in rearing a city, in framing a commonwealth: why may not several deities combine in contriving and framing a world? This is only so much greater similarity to human affairs. By sharing the work among several, we may so much further limit the attributes of each, and get rid of that extensive power and knowledge, which must be supposed in one deity, and which, according to you, can only serve to weaken the proof of his existence. And if such foolish, such vicious creatures as man can yet often unite in framing and executing one plan; how much more those deities or dæmons, whom we may suppose several degrees more perfect? $(1964,413)$

A final dissimilarity concerns the fact that all known causal and intelligent agents are embodied, while God, at least within many theological perspectives, is regarded as incorporeal. Rāmānuja stresses that there is no evidence of conscious causal efficacy on the part of an intelligent agent unless the agent is conjoined with a physical body, so the design inference is considerably weakened. Hume presses the same basic point, that God, or gods, if truly similar to human agents as the design argument requires, must be 
corporeal. After first suggesting that the gods, to be similar, should even be mortal and reproduce by sexual generation as the ancient theogonies in the West had it, Hume proposes that for a still more perfect anthropomorphism - thereby strengthening the inferences drawn from the design argument- the deities should have eyes, noses, mouths, ears, and the like $(1964,414)$.

Hume then takes the matter of divine corporeality one step further and proceeds to offer an extraordinary model of the universe — extraordinary at least to the theists of his day:

Now if we survey the universe, so far as it falls under our knowledge, it bears a great resemblance to an animal or organized body, and seems actuated with a like principle of life and motion. A continual circulation of matter in it produces no disorder: a continual waste in every part is incessantly repaired: the closest sympathy is perceived throughout the entire system: and each part or member, in performing its proper offices, operates both to its own preservation and to that of the whole. The world, therefore, I infer, is an animal, and the Deity is the SOUL of the world, actuating it, and activated by it. $(1964,416)$

Hume again refers to the theories of the ancients, noting that the animal model of the cosmos was the prevalent one:

For though sometimes the ancient philosophers reason from final causes, as if they thought the world the workmanship of God; yet it appears rather their favourite notion to consider it as his body, whose organization renders it subservient to him. And it must be confessed, that as the universe resembles more a human body than it does the works of human art and contrivance; if our limited analogy could ever, with any propriety, be extended to the whole of nature, the inference seems juster in favour of the ancient than the modern theory. $(1964,416)$

From Hume's perspective, Rāmānuja's body-soul model of the universe and God would in the end be more plausible than Mill's favored mechanistic model!

Implications of the Classical Design Arguments for Modern Hindu Receptions of Darwinisim. Both in India and the West until the discoveries and conclusions of Darwin, there was little way of avoiding an either/or way of thinking about the origin of animal species. Either organisms with their apparent design were in fact designed, or they were the result of chance, a view that even today lacks credibility. A third alternative, that of gradual adaptation of means to end, and of animals to their habitats, by the process of 
natural selection working on minute and chance variations over an immense period of time, was far from obvious, if not inconceivable in the context of the times (cf. Stephen Jay Gould 1993, 143-46; Michael Ruse 2003, 43-44).

In India, diversity of species, as of social classes, was generally explained in terms of the law of karma, a compelling notion within a Hindu context, even if without empirical support. The classical Hindu design proponents thus frequently found themselves countering not so much purely materialistic arguments for the self-development of matter-although the materialist Cārvākas were repeatedly if somewhat needlessly condemned given their lack of popularity_ but with arguments against the idea that karmic force (adrșta) by itself, without God, could account for diversity in the world. The consequent intertwining of moral, karmic arguments with traditional mechanistic design arguments was to create a generally inhospitable climate for the introduction of Darwinian thinking into India in the nineteenth century. Such intertwining resulted in a relatively static model of organic life that may be termed the Great Karmic Chain of Being, as resistant to evolutionary thinking as the western notion of a Great Chain of Being.

In the several centuries after Rāmānuja up to the time of British rule in India, the classical Hindu design arguments remained little developed beyond Udayana's masterful elaborations. During the first few decades of British colonialism the classical arguments were once again called upon—now often to defend against the combined onslaught of Protestant missionary evangelism, European skeptical rationalism and scientific materialism, and by the end of the nineteenth century even against Darwinism itself, one of the greatest contemporary challenges to design notions in any culture. At the same time, by mid-century the rationalistic approach to God represented by the design argument came to be looked upon with increasing suspicion by many of the western-educated, Hindu intellectual elites-a development following on the heels of a similar European disillusionment with natural theology and deistic modes of thought that had already begun to lose their force in the West by the beginning of the nineteenth century.

The reassertion of the classical design arguments in British India began early in the nineteenth century with Rammohun Roy (1772-1833), founder of the Brahmo Samaj. Rammohun eagerly embraced traditional Hindu design arguments in an effort to show that Hinduism is truly monotheistic and in no way inferior to Christianity. In his first English work Rammohun writes: 
We see the multifarious, wonderful universe, as well as the birth, existence, and annihilation of its different parts; hence, we naturally infer the existence of a Being who regulates the whole, and call him Supreme: in the same manner as from the sight of a pot we conclude the existence of its artificer.

... and the Vedanta thus declares: "Nature is not the Creator of the world not being represented so by the Veda," for it expressly says, "God has by his sight created the Universe." Nature is an insensible Being, she is, therefore, void of sight or intention, and consequently unable to create the regular world.

Atoms are not supposed to be the cause of the world....Because an atom is an insensible particle, and from the above [Vedic] authority it is proved, that no Being void of understanding can be the author of a system so skillfully arranged. (Roy 1978, 7-9)

These ideas clearly reflect the design arguments of both Śankara and Udayana. In his English writings, as Dermot Killingley points out, Rammohun tends "to adapt Vedānta to the rational theism of contemporary Europe" (Killingley 1993, 44). In the process of developing his Vedāntic Deism, Rammohun excoriated the Christian missionaries for their Trinitarian adherence to three gods, since the design argument, in his view, points conclusively to one creator alone.

Rammohun's successors in the Brahmo Samaj, Debendranath Tagore (1817-1905) and Keshab Chandra Sen (1838-1884), each in his own way, became increasingly uncomfortable with Rammohun's Vedāntic Deism, apprehensive about the agnostic and materialistic implications of design arguments with their removal of God from personal interaction with the ongoing world. Both Debendranath and Keshab drew increasingly upon personal, experiential, and mystical "evidence" or "yogic perception" for proving the existence of God. ${ }^{49}$ However, Dayananda Saraswati (1824-1883), founder of the Arya Samaj, fully embraced the design argument in its Vaiśeșika version, wielding it against his Christian opponents especially with regards to the latter's notion of God's creation of the universe "out of nothing," a dogma lacking any support from the design argument in itself from his perspective. ${ }^{50}$

In the last quarter of the nineteenth century we find Hindu intellectuals beginning to grapple with the challenges of Darwinian evolution that first appeared in the West with the publication of his Origin of Species in 1859. Two of the earliest Hindu thinkers to respond were the above-mentioned Keshab Chandra 
Sen and Dayananda Saraswati. The latter, with his passionate embrace of the atomistic design arguments, not surprisingly dismissed Darwin arguing that "If man descended from monkeys, how is it that process had come to an end and monkeys no longer evolve into men" (quoted by Ganga Ram Garg 1984, 70). Darwin's teachings were opposed to those of the Veda which are in harmony with science, according to Dayananda. Further, Dayananda accepted Udayana's notion that both humans and all human culture are reestablished at the beginning of each cosmic cycle, thereby discounting any general evolutionary history of humankind, organic and cultural, as well as dismissing any sort of progress in the scientific understanding of the world. ${ }^{51}$

Keshab was more open to notions of organic evolution, seeing evolution as "the great idea of the day" (Sen 1940, 340-41) and even suggesting that the traditional doctrine of the ten avataras of Viṣnu anticipated the stages of animal development proposed by evolutionary theory. ${ }^{52}$ But Keshab was little interested in the scientific details of organic evolution such as natural selection, instead taking over many of its general ideas and applying them to the notion of spiritual evolution. In the process, he developed, perhaps despite himself, a rather unbreachable dichotomy between natural science as developed in the West and "mystical science" as discovered by the ancient Hindu yogis who, in Keshab's mind, went far beyond Darwin. Keshab's general approach was greatly elaborated upon by Swami Vivekananda (1863-1902).

Vivekananda dismissed traditional design arguments as appropriate only for young children and as unscientific in nature $(2003,6: 97)$. His disparagement of design arguments seems to reflect in part the traditional Advaitin notion of two levels of truth, design notions belonging to the lower, mundane level of knowledge. The non-teleological nature of the absolute, reflecting traditional Hindu concerns about God's motivation underlying creation, becomes part of the standard Neo-Advaitin critique of the design argument. ${ }^{53}$ Such was the Swami's influence that only recently, as in the International Society for Krishna Consciousness with its fierce anti-evolutionism, combined with its non-Advaitin perspective, do we see revivals of the design argument in a Hindu context. At the same time, Vivekananda's insistence upon the complete harmony of Advaita with modern science while simultaneously proclaiming the radical incompleteness of evolutionary theory without the inclusion of the reverse involutionary process of consciousness descending into matter inevitably led to a thorough undermining of a robust Darwinism. Vivekananda's ideas on involution and evolution set the general framework for many of the major 
twentieth-century Hindu responses to organic evolution. Thus, even those western-educated Hindu thinkers like Aurobindo Ghose and Sarvepalli Radhakrishnan who espoused modern science and even evolutionary ideas on a general level denied that the human organism could have evolved from lower animal forms, since each species has its own special nature (svabhāva).

In conclusion, I may note one of the most remarkable ideas in Hume's Dialogues Concerning Natural Religion: his anticipation of Darwin's theory of evolution, including a process involving a crude form of natural selection (1964, 427-29). His striking evolutionary proposal, given its use of organic imagery — likening a new universe to a feeble embryo, or a dead universe to a rotten carcass - may well have been inspired by his general preference for an organic model of reality. It seems probable, in any case, that organic rather than mechanistic models of the universe are more amenable to Darwinian evolutionary ideas. It is interesting to speculate how western-educated Hindus in the nineteenth and twentieth centuries might have responded more positively to the introduction of Darwinian evolution if they had been less influenced by the Advaita of Śankara or the theistic Vaiśeșika of Udayana and more by the organic Viśiștādvaita of Rāmānuja. 


\section{References}

Annambhaț̣. 1976. Tarkasai்graha-Dīpikā on Tarakasai்graham. In Tarkasamingaha-Dīpikā on Tarakasamgraham by Annambhațta. Trans. Gopinath Bhattacharya. Calcutta: Progressive Publishers.

Bhattacharyya, Gopikamohan. 1961. Studies in Nyāya-Vaiśsșika Theism. Calcutta: Sanskrit College.

Boyle, Robert. [1666] 1979. "The Origin of Forms and Qualities According to the Corpuscular Philosophy." In M. A. Stewart, ed., Selected Philosophical Papers of Robert Boyle, 1-96. Manchester: Manchester Univ. Press.

Brown, C. Mackenzie. 2007. “The Western Roots of Avataric Evolutionism in Colonial India.” Zygon 42, no. 2 (June 2007): 425-49.

Chakrabarti, Kisor Kumar. 1999. Classical Indian Philosophy of Mind: The Nyāya Dualist Tradition. Albany: State Univ. of New York Press.

Chattopadhyaya, Debiprasad. 1964. Indian Philosophy: A Popular Introduction. New Delhi: People’s Publishing House.

Chemparathy, George. 1972. An Indian Rational Theology: Introduction to Udayana's Nyāyakusumāñjali. Vienna: Indologisches Institut der Universitat Wien.

Clooney, Francis X. 1993. Theology after Vedānta: An Experiment in Comparative Theology. Albany: State Univ. of New York Press.

Cowell, Edward B., ed. and trans. [1864] 1979. The Kusumānjali, or Hindu Proof of the Existence of a Supreme Being, by Udayana Acharya, with the Commentary of Hari Dasa Bhattachaaarya. Delhi: Caxston.

Dawkins, Richard. 2006. The God Delusion. Boston and New York: Houghton Mifflin Company.

Dayananda Saraswati. 1970. An English Translation of the Satyarth Prakash, Literally: Expose of Right Sense (of Vedic Religion) of Maharshi Swami Dayananda Saraswati, "The Luther of India," Being a Guide to Vedic Hermeneutics, trans. Shri Durga Prasad.. 2nd ed. New Delhi: Jan Gyan Prakashan. 
Dravid, N. S. 1996. See Udayana 1996.

Garg, Ganga Ram. 1984. World Perspectives on Swami Dayananda Saraswati. New Delhi: Concept Publishing Co.

Goel, Aruna. 1984. Indian Philosophy: Nyāya-Vaiśeșika and Modern Science. New Delhi: Sterling Publishers.

Gould, Stephen Jay. 1993. "Darwin and Paley Meet the Invisible Hand." In Stephen Jay Gould, Eight Little Piggies: Reflections in natural History, 138-52. New York: W. W. Norton \& Co.

Hiriyanna, M. 1932. Outlines of Indian Philosophy. London: George Allen \& Unwin., Ltd. 1949. The Essentials of Indian Philosophy. London: George Allen \& Unwin., Ltd.

Hume, David. 1964. A Treatise of Human Nature: Being an Attempt to Introduce the Experimental Method of Reasoning into Moral Subjects; and Dialogues Concerning Natural Religion. Vol. 2. Aalen, Germany: Scientia Verlag.

Keith, Arthur Berriedale. 1921. Indian Logic and Atomism: An Exposition of the Nyāya and Vaiśeșika Systems. Oxford: Oxford Univ. Press.

Keshub Chunder Sen. 1940. "Philosophy and Madness in Religion.” In Life and Works of Brahmananda Keshav, ed. Prem Sundar Basu, 334-45. Calcutta: Navavidhan Publication Committee. . 1979. “Great Men.” In Keshub Chunder Sen, ed. David C. Scott, 73-100. Madras: The Christian Literature Society.

Killingley, Dermot [Hastings]. 1993. Rammohun Roy in Hindu and Christian Tradition; The Teape Lectures 1990. Newcastle upon Tyne: Grevatt \& Grevatt.

King, Richard. 1999. Indian Philosophy: An Introduction to Hindu and Buddhist Thought. Washington, D.C.: Georgetown University Press.

Klostermaier, Klaus K. 1994. A Survey of Hinduism. $2^{\text {nd }}$ ed. Albany: State Univ. of New York Press.

Larson, Gerald James. 1969. Classical Sāmkhya: An Interpretation of Its History and Meaning. Delhi: Motilal Banarsidass.

Mādhava [Mādhavācārya]. 1981. Sarva-Darśana-Sañgraha of Mādhavācārya: Sanskrit Text, English Translation, Notes \& Appendix. Trans. E. B. Cowell and A. E. Gough. Ed. K. L. Joshi. Ahmedabad: Parimal Publications. 
Majeed, Javed. 1992. Ungoverned Imaginings: James Mill's The History of British India and Orientalism. Oxford: Oxford Univ. Press.

Matila, Bimal Krishna. 1977. "Kiraṇāvalī on Prasśastapāda’s Padārthadharma-Samgraha." In Encyclopedia of Indian Philosophies: Indian Metaphysics and Epistemology: The Tradition of Nyāya-Vaiśeșika up to Gañgeśa, ed. Karl H. Potter, 589-603. Princeton: Princeton Univ. Press.

Mill, James. 1820. The History of British India. $2^{\text {nd }}$ ed. 6 vols. London: Baldwin, Cradock, and Joy.

Murty, K. Satchidananda. 1959. Revelation and Reason in Advaita Vedānta. Waltair: Andhra University.

Olson, Richard G. 2004. Science and Religion, 1450-1900: From Copernicus to Darwin. Balltimore: Johns Hopkins Univ. Press.

Paley, William. [1802] n.d. Natural Theology. New York: American Tract Society. [Reprinted "from a late London edition" and published together with Paley's Horae Paulinae in a single volume entitled Paley's Natural Theology and Horae Paulinae.]

Peacocke, Arthur. 1990. Theology for a Scientific Age: Being and Becoming-Natural, Divine and Human. Enlarged edition. London: SCM Press.

Phillips, Stephen. 1995. Classical Indian Metaphysics: Refutations of Realism and the Emergence of “New Logic.” Chicago: Open Court.

Plato. 1961. Laws. Trans. By A. E. Taylor. In Edith Hamilton and Huntington Cairns, eds., The Collected Dailogues of Plato, Including the Letters, 1225-1513. New York: Bollingen Foundation.

Potter, Karl H. 1977. "Introduction to the Philosophy of the Nyāya-Vaiśeșika." In Encyclopedia of Indian Philosophies: Indian Metaphysics and Epistemology: The Tradition of Nyāya-Vaiśeșika up to Gangeśa, ed. Karl H. Potter, 1-208. Princeton: Princeton Univ. Press.

1981. "Brahmasūtrabhāṣya." In Encyclopedia of Indian Philosophies: Advaita Vedānta up to Śamkkara and His Pupils, ed. Karl H. Potter, 119-80. Princeton: Princeton Univ. Press.

Potter, Karl H., and Sibajiban Bhattacharya. 1977. "Nyāyakusumāñjali." In Encyclopedia of Indian Philosophies: Indian Metaphysics and Epistemology: The Tradition of Nyāya-Vaiśeșika up to Gañgeśa, ed. Karl H. Potter, 557-588. Princeton: Princeton Univ. Press.

Praśastapāda. 1982. Padārthadharmasañgraha of Praśastapāda with the Nyāyakandalī of Śrīdhara. Trans. Mahāmahopādhyāya Gañgānātha Jhā. Varanasi and Delhi: Chaukhambha orientalia. 
1984. $2^{\text {nd }}$ ed. [Padārthadharmasangraha] The Praśastapāda Bhāshya with Commentary Nyāyakandali of Sridhara. Sanskrit, with English title page. Ed. Vindhyesvari Prasad Dvivedin. Delhi: Sri satguru Publications.

Raju, P. T. 1985. Structural Depths of Indian Thought. Albany: State Univ. of New York Press.

Ram-Prasad, Chakravarthi. 2001. Knowledge and Liberation in Classical Indian Thought. Hampshire and New York: Palgrave.

Rāmānuja. N.d. Śrī Rāmānuja Gītā Bhāssya: with Text in Devanagari \& English Rendering, and Index of First Lines of Verses. Tr. Svāmī Ādidevānanda. Mylapore, Madras: Sri Ramakrishna Math. 1995. Śrībhāṣyam. Melukote, India: Saṃskṛta-Saṃśodhana-Saṃsat.

Ramatirtha, Swami. 1930-1932. $5^{\text {th }}$ ed. In the Woods of God-Realization: Or, Complete Works of Swami Rama Tirtha. 8 vols. Lucknow: Rama Tirtha Publication League.

Rambachand, Anantanand. 2006. The Advaita Worldview: God, World, and Humanity. Albany: State Univ. of New York Press.

Roy, Rammohun. 1978. "Translation of an Abridgment of the Vedant, or The Resolution of all the Veds; The Most Celebrated and Revered Work of Brahmunical Theology; Establishing the Unity of the Supreme Being; and that He Alone Is the Object of Propitiation and Worship." In Rammohun Roy, The English Works of Raja Rammohun Roy, with an English Translation of "Tuhfatul Muwahhiddin," 1-17. Reprint of the 1906 ed. New York: AMS Press.

Ruse, Michael. 2003. Darwin and Design: Does Evolution have a Purpose? Cambridge: Harvard Univ. Press.

Śankara. 1983. Brahmasutra Bhashya, rev. ed., 1983. Complete Works of Sri Sankaracharya in the Original Sanskrit, vol. VII. Madras: Samata Books.

Sharma, B. N. K. 1986. The Brahmasūtras and Their Principal Commentaries: A Critical Exposition. 2 vols. $2^{\text {nd }}$ ed. New Delhi: Munshiram Manoharlal.

Sharma, Chandradhar. 1964. A Critical Survey of Indian Philosophy. Delhi: Motilal Banarsidass.

Singh, Bawa Chajju. 1903. The life and Teachings of Swami Dayanand Saraswati. Lahore: Pratinidhi Sabha. 
Sinha, Baswati. 1999. Nyāyakusumāñjali: Hindu Rational Enquiry into the Existence of God; Interpretive Exposition of Udayanācārya's Auto-commentary with Translation of kārikās. New Delhi: Aryan Books International.

Smart, Ninian. 1964. Doctrine and Argument in Indian Philosophy. London: George Allen and Unwin LTD.

Tagore, Devendranath. 1928. Brahmo Dharma of Maharshi Debendranath Tagore. Translated by Hem Chandra Sarkar. Calcutta: H. C. Sarkar.

Udayana. 1995. Atmatattvaviveka by Udayanācārya, with Translation, Explanation and AnalyticalCritical Survey. Sanskrit text with translation and explanation by N. S. Dravid. Shimla: Indian Institute of Advanced Study.

. 1996. Nyāyakusumā̃̃̃jali of Udayanācārya. Sanskrit text with translation and explanation by N. S. Dravid. Vol. 1. New Delhi: Indian Council of Philosophical Research.

Uḍ̣̣yoṭakara. 1984. Nyāya-Vārțika. In Mahāmahopādhyāya Gañgānātha Jhā, trans. The Nyāya-Sūtras of Gauțama with the Bhāṣya of Vātsyāyana and the Vārțika of Uḍ̂tyoțakara. 4 vols. Delhi, Varanasi, Patna, and Madras: Motilal Banarsidass.

Varadachari, V. 1977. “Ātmatattvaviveka.” In Encyclopedia of Indian Philosophies: Indian Metaphysics and Epistemology: The Tradition of Nyāya-Vaiśeșika up to Gangeśa, ed. Karl H. Potter, 526-557. Princeton: Princeton Univ. Press.

Vivekananda, Swami. 2003. The Complete Works of Swami Vivekananda. 9 vols. In Swami Vivekananda: Life, Works \&Research (multimedia CD). Calcutta: Advaita Ashrama.

Ward, William. [1817-1820] 1985. History, Literature, and Mythology of the Hindoos: Including a Minute Description of Their Manners and Customs, and Translations from their Principal Works. $3^{\text {rd }}$ ed. 4 vols. Delhi: B. R. Publishing Corp. 
${ }^{1}$ This distant observer, James Mill, took great pride in not having traveled to India, and in his almost complete ignorance of any Indian languages. Such lack of immediate familiarity with India, in his view, provided him with a more objective perspective from which to comprehend, synthesize, and evaluate the works of others who had been more intimately involved with Indian culture, and thus more likely tainted by personal considerations, expectations, limited experiences, and emotional reactions to India and Indians (Mill 1820, I:ix-xxv). While such a view seems almost incredible for today's scholars, Mill was convinced that people who had spent considerable time in India and had learned something of their languages, like Sir William Jones, had romanticized their subject and gotten India completely wrong.

${ }^{2}$ The three quotations above are from James Mill 1820, I:287, I:329, and I:329-31, respectively.

${ }^{3}$ The word sounds is Ward's literal translation of the Sanskrit term śabda, which also refers to the spoken word, and hence to verbal authority, both of a sage and of scripture. It is one of the main means of valid knowledge (pramañas) accepted by several of the orthodox schools, along with perception and inference.

${ }^{4}$ Gopikamohan Bhattacharyya (1961, xiii) includes the Vedānta, as well as the Mīmāṃsa and Sāṃkhya, among the orthodox schools that agree "in denouncing the concept of God as the Ultimate Reality." He seems to have in mind primarily the Advaita Vedānta, for the other Vedāntic schools like Rāmānuja's are clearly theistic. Similarly, Chandradhar Sharma (1964, 209-10), after briefly summarizing the various Nyāya-Vaiśeșika arguments for the existence of God, concludes that these arguments all fall short, and thus the Vedāntins, including Śankkara as well as Rāmānuja, "have rejected the Nyāya arguments and have fallen back on the Shruti [scripture] alone for the existence of God." But Śankara, as we shall see, grants a qualified reality to God, and on this qualified level—of mundane reality—puts forth vigorous arguments for the existence of God.

5 Post-Śankara Advaita developed the technical term vivārta to distinguish the merely apparent manifestation of Brahman as the world from a real modification, parināma, (see Richard King 1999, 220). While Śankara may not have used the term vivārta in this technical sense, he clearly depends at times on the general concept of merely apparent manifestation to justify various aspects of his interpretation of the Brahman-world relationship. There have been a number of recent attempts to interpret Śankara as holding to a rather positive view of the world. These efforts see Śankara as providing the world with a greater 
reality and value than traditional scholarship has ascribed to his Advaita, even seeing the world for Śankara as a "celebrative expression of Brahman" (Anantanand Rambachand 2006, 76-80). Such interpretations emphasize the dependence of the world on Brahman, and the difference of Brahman from the world even though the world is not different from Brahman. This paradox is explained in terms of the classic Advaita notion that the relationship of the world to Brahman is an ineffable mystery (anirvacaniya). Such an answer, however, when applied to the problem of evil, is quite problematic. Śankara in such contexts, as we shall see, prefers the notion that suffering is not so much a mystery as simply part of our deluded world view that takes the world too seriously — in effect, arguing that the world with all its apparent suffering is an illusion, not what we experience it to be.

${ }^{6}$ All translations from Sanskrit are my own unless otherwise indicated.

${ }^{7}$ In many cultures the apparent arrangement of the universe has seemed "self-evident" to certain kinds of philosophers. For instance, David Hume in his Dialogues Concerning Natural Religion $(1964,400)$ has the traditional defender of theism, Cleanthes, argue that theists have no need to "prove the similarity of the works of Nature to those of Art; because this similarity is self-evident and undeniable."

${ }^{8}$ Karl H. Potter, in his useful summary of Śankara's arguments in the Vedānta Sütras, ignores the design implications of Śankkara's comment on this aphorism (Potter 1981, "Brahmasūtrabhāṣya,” 123).

${ }^{9}$ But as Clooney points out, these rational refutations are not meant to shift "the analysis to a forum where reason would be the primary standard," but rather just to show the implausibility, on rational grounds, of opposing views. Needless to say, the various opponents, including the Sāmkhyas, are not presented in "a 'real-life' debate," as the whole is orchestrated to produce a clear victory for the Advaitin side (Clooney 1993, 107). Clooney further notes that the opposing "represented schools might well have other views of the issues involved or of how to present themselves" 1993, 108).

${ }^{10}$ The idea that the effect pre-exists in its cause is usually referred to as satkārya. This latter term appears, for instance, in Sāmphyy-Kārikā 9 (the Sanskrit text of the Sāmkhya-Kārikā is available in Gerald James Larson 1969, 257-82).

${ }^{11}$ Śankara, like William Paley, is impressed with the level of skill on the part of the cosmic architect in arranging the world, a skill well beyond the understanding of human craftsmen. Cf. Paley n.d, p. 20. 
${ }^{12}$ This last line basically repeats the original sūtra of Bādarāyana, having clarified the reasoning behind it with various examples.

${ }^{13}$ For a discussion of the possible innate purposeful creativity of Brahman, see Rambacahnd 2006, 91-96, yet as the quotation above indicates, Śankara in this context clearly distinguishes between innate propensities of the Lord and desires or purposes as we normally understand them.

${ }^{14}$ Cf. Robert Boyle $(1979,19)$, who affirms "that the origin of motion in matter is from God; and not only so, but that thinking it very unfit to be believed that matter, barely put into motion and left to itself, should casually constitute this beautiful and orderly world, I think also further that the wise author of things did, by establishing the laws of motion among bodies and by guiding the first motions of the small part of matter, bring them to convene after the manner requisite to compose the world...." We may note here the close intertwining of cosmological and teleological considerations. We find such a juxtaposition as early as Plato (Laws, book X).

${ }^{15}$ Potter $(1977,7)$ agrees, asserting that the Kusumāñjali "contains by general acclaim the definitive treatment of the question of how to prove God's existence."

${ }^{16}$ Potter $(1977,12)$ similarly claims that the two schools "from the first considered themselves to be mutually supportive...."

17 There is some debate over whether the Nyāya-Vaiśeșika was originally atheistic (see Gopikamohan Bhattacarrya 1961, 160-63; Arthur Berriedale Keith 1921, 264-66; Hiriyyanna 1932, 242). At the very least, significant theistic issues and arguments are not found in the sūtras of Kaṇāda and Gautama, so that any theism is only implicit at best. The first clear inclusion of the concept of God as creator in the Nyāya and Vaiśeșika writings is in Praśastapāda's commentary (ca. fifth century C.E.) on Kaṇāda's VaiśeșikaSütra (Hiriyanna 1932, 226). Karl H. Potter mentions Vātsyāyana (c. 400 c.e.), commentator on the Nyāya Sütra of Gautama, as attempting "to introduce theistic readings into otherwise innocent passages" (1963, 248). See also Chakravarthi Ram-Prasad's illuminating discussion of theism in the Nyāya (2001, 100-07), and the absence of any real role for God in the early Nyāya writings. Stephen H. Phillips $(1995,67,69)$ summarizes the situation nicely: "The theistic affinities of later Nyāya-Vaiśeșika are probably best understood as reflecting broad-based cultural movements....My impression is that a vague theological 
universalism was honored culturally, and that Udayana's apparent endorsement of it is mostly handwaving."

${ }^{18}$ Cf. Gopikamohan Bhattaccharyya 1961, 22-23). For a summary of Vatsyana's moral argument, see also Potter 1977, Indian Metaphysics and Epistemology, p. 263; for Uddyotakara, pp. 331-333.

${ }^{19}$ Udayana 1996, 1.

${ }^{20}$ Chemparathy further explains: “...among the opponents [of Udayana] the Vedāntins are less often mentioned or refuted in his works than the Mīmāṃsakas, Sāṃkhyins or Cārvākas. This is especially remarkable in the Nyāyakusumāñjali where only once the view of a Vedāntin, namely Bhāskara, is mentioned together with the views of some others concerning the factor that determines a new creation after dissolution" $(1972,31)$.

${ }^{21}$ Near the beginning of the fifth bouquet, Udayana lists, by means of one word definitions, eight positive arguments for God's existence. These are: 1) "kārya" (effect), 2) “āyojana" (combination), 3) "dhṛtyādi” (support, etc.), 4) "pada" (usage), 5) "pratyayata" (authority or conviction based on settled belief), 6) "śruti" (scripture), 7) "vākya" (sentences), and 8) "saṃkhyā" (number). As indicated, we shall focus primarily on the first four of these. The last four are less directly relevant to the design argument and will be mentioned only as they may relate to the first four. The argument about pratyayata or authority concerns the reliability of scripture that produces confidence in the people. This argument is related to the one regarding pada, usage, which as defined by Udayana refers to ordinary usages such as crafts and the alphabet. The alleged need for humans to be taught these usages at the beginning of each creation can be extended logically to refer to the revelation of scripture as well at the beginning of each creation, and thus is related to the issue of scriptural authority. Udayana's sixth argument, simply termed śruti or scripture, refers specifically to the closely related idea that Vedas of any sort, like Ayurveda, are the creation of sentient beings, and thus the scriptures known as the Vedas must also be the production of a sentient being (contrary to the Mīmāṃsaka position that the Vedas are eternal). As the Vedas are composed of sentences, $v \bar{a} k y a$, and sentences are the creation of intelligent beings, once again the createdness of the Vedas is shown. Finally, the argument from samkhyā or number is highly technical and depends upon details peculiar to Nyāya-Vaiśeșika ontology, but boils down simply to the notion that the capacity of infinitely small atoms to form objects of magnitude through combinations into dyads and triads depends upon a 
cognizing causal agent, which must be God. To complicate matters, each of the eight arguments can be interpreted as directed against the Sāp̣khya, and in another manner, against the Mimamsaka. Most relevant for us are the arguments as interpreted against the Sāmkhya. For discussion of these arguments in detail, see Bhattacharyya 1961, 133-37. A brief summary is given in Aruna Goel 1984, 152-58.

${ }^{22}$ P. T. Raju $(1985,221)$ notes that the Nyāya causal argument for the existence of God "is actually a combination of the western causal and teleological arguments."

${ }^{23}$ Klaus K. Klostermaier, like many others, asserts that the arguments for the existence of God in the Kusumañjali and other Nyāya works are "quite unique in Indian philosophy" (1994, 395), but many of Udayana's arguments are simply elaborations upon earlier Nyāya versions and of Śankkara's arguments in his Vedānta Sütra Bhāṣya.

${ }^{24}$ The latter quotation also appears in Chemparathy 1972, 44. He notes, in partial defense of Cowell, that Cowell himself had only the verse portions of the Kusumāñjali before him, and thus "was not in a position to make an adequate study of Udayana or sufficiently appreciate his contribution" $(1972,44)$.

${ }^{25}$ My translation, from the Sanskrit text of the Kiranāavali provided by Chemparathy 1972, 88. A useful summary of the Kiranāavali's arguments for the existence of God is provided by Bimal Krishna Matilal $1977,594$.

${ }^{26}$ Mādhava discusses the causal argument and the problem of a disembodied creator in his Sarva-DarśanaSangraha, with specific reference to Udayana’s Kusumāñjali (Mādhava 1981, 240-43).

${ }^{27}$ The phenomenon of such stone-encased frogs, and lizards, has been widely observed for centuries, and today there are a number of naturalistic explanations for such. These include the burrowing of a small frog into soft mud during the rainy season, the mud later drying to a rock-solid hardness entrapping the creature but which still can survive for many months if it has any slight access to air. Also, the evidence (the broken rock) is hardly ever examined before it was broken - why would one, until one found a most unexpected creature inside? - thus making it difficult to confirm how truly sealed over the whole "rock" was. For further information, see astronomer David Darling's on-line Science Encyclopedia at:

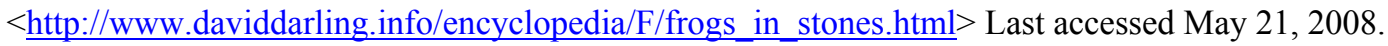

${ }^{28}$ A brief summary of Udayana's arguments for God's disembodied creative activity may be found in V. Varadachari 1977, 555. 
${ }^{29}$ The mind/body problem is complicated both in the Christian and the Hindu context by, among other things, the various meanings given to "mind." In the Hindu case, in Samkhya mind (manas) is an evolute of Primal Matter and thus material in nature and distinct from spirit, which alone is conscious. In Vaiśeșika, manas along with soul (Ātman) is immaterial. The critical issue, however phrased, is how an immaterial or disembodied conscious agent—call it spirit, soul, or mind — can exert influence on a material body. For an excellent summary of some of the key issues involved in the context of Christian theology and the twin problems of mechanistic determination and mind/body dualism, see Arthur Peacocke's discussion of the "causal joint" problem of how mind interacts with body (1990, 148-51). He writes: "It is indeed difficult to imagine how God might be an agent in a world conceived of as ruled by deterministic laws at all levels when the only analogy for such agency has itself been formulated in dualistic terms that involve a gap dividing action in the 'body', and so in the natural world, from intentions and other acts of the "mind" $(1990,148)$. Peacocke notes that most theologians simply assert that there is a causal link, without real explanation or justification. Clearly Hindu theologians were aware of the difficulty, and in the end, like their western counterparts, tend to resort to mere assertion that disembodied causation is possible, with perhaps a "supernatural" example thrown in as justification, as Udayana does.

${ }^{30}$ A good, literal translation of the text may be found in Praśastapāda 1982, 108-111.

${ }^{31}$ Compare the statement in the Tarkasamgraha-Dipikā of Annambhatța, an eighteenth century NyāyaVaiśeșika philosopher: "[Rational proof of God is possible] on account of the validity of the inference that the initial sprouting of the earth and such things are brought about by a causal agent because they are effects, like pots. Causal agency means being endowed with volition, desire to create, and immediate cognition of the range of perceptible objects that constitute the material cause" (Annambhatța 1976, XII [for transliterated text in the next to last section of the volume], and 7-8 [for the Devanagiri text in the last section of the volume]). (Cf. Gopinathan Bhattacharya's elucidation of the meaning of causal agent [1976, 94].) In commenting on this passage, Kisor Kumar Chakrabarti notes that the logic of Annambhațta's argument does not rule out someone making an automaton that, while lacking perception and so on, could still create pots; this simply removes the intelligent designer one step back, to designing the automaton that makes the pot. This parallels in a way Paley's introduction of a replicating watch in elaborating upon his famous analogy (Paley n.d., 14-19). In either case, pot-producing automaton or replicating watch, the 
productive machine constitutes evidence of a prior causal agent. As Paley explains, the discovery of the replicating ability of the watch would simply "increase beyond measure our admiration of the skill which had been employed in the formation of such a machine" (n.d., 19). In Chakrabarti's interpretation of the robotic pot-maker: "the designer of such an automaton may be regarded as an agent through an indirect (paramparā) relationship" $(1999,163)$.

${ }^{32}$ Cf. Chemparathy 1972, 90. Regarding the frequent use "like an axe and so on," Chakrabarti writes: "The words 'such as a pot and so on' are intended to be a summary of the inductive evidence in support of the general claim. The words 'and so on' are usually added to the particular specimen cited to make it clearer that it is a summary" 1999,164$)$.

${ }^{33}$ This assumption of the necessity for volitional activity to introduce motion into matter is relatively late in the Nyāya-Vaiśeșika. As Smart notes: “...Atomism of the early period was not theistic, and such concepts as gravity (to explain the falling of bodies), unseen force (to explain the circulation of fluids in plants and so on), etc., indicated that no intrinsic difficulty was felt in assigning motion to inanimate objects quite independently of volitional activity" $(1964,156)$. For a brief discussion of the problem of motion and the absence of theism in Kạ̣āda, see Bhattacharyya 1961, 162, and Keith 1921, 221-24.

${ }^{34}$ Goel draws attention to the fact that the atomism of the Greek philosophers Epicurus and Democritus, unlike that of the Indian Rational Atomists, posited that atoms have their own motion $(1984,117)$. Thus, the religious attacks on atomism in the West focused on the problem of how "chance collisions" of atoms could create the ordered universe, while in India, the additional problem of how atoms could become active in the first place was often the center of attention. See also Debiprasad Chattopadhyaya $(1964,173)$ on the "autodynamic" or "natural-law obeying" atoms of Democritus and his rejection of the God-solution to atomic motion.

${ }^{35}$ According to Chemparathy, the maintenance-and-destruction arguments for the existence of God are new in Udayana $(1972,184)$.

${ }^{36}$ A contemporary example of this folk physics is provided by Richard Dawkins' in his The God Delusion. Dawkins quotes from a "recovering theist" regarding her first experiment with the idea that there is no God: "I'm embarrassed to report that I initially felt dizzy. I actually had the thought, 'Well, how does the Earth 
stay up in the sky? You mean, we're just hurtling through space? That's so vulnerable!' I wanted to run out and catch the Earth as it fell out of space into my hands" (Dawkins 2006, 324).

${ }^{37}$ Isaac Newton would perhaps not have been entirely unsympathetic to Udayana. The discoverer of the law of gravity was sufficiently impressed by the order and regularity of the planetary system that he inferred a designing god to set up the basic orbits of the planets around the sun. But Newton realized that his own discovery required an infinite universe, to avoid a big crunch of all celestial bodies in a central point, if the universe were finite. Once gravitation is connected with the mass of bodies, rather than with a specified direction, centeredness rather than downwardness becomes a key notion, a notion that would undermine Udayana's argument, at least in the form he presents. And if the bodies are drifting in infinite space, then even centeredness no longer makes sense-although current scientific controversies address this very question as to whether the universe is finite or infinite.

To harmonize Udayana's argument with modern science, N. S. Dravid, argues: "The gravitational and other forces which according to modern science keep the universe going do themselves require some cause to support them" (Dravid 1995, 375). I suppose Udayana himself might have accepted such a viewpoint, given his acceptance of indirect causation, had he known about such laws of nature as gravity (rather than just heaviness).

${ }^{38}$ Cf. K. Satchidananda Murty 1959, 195.

${ }^{39}$ Cf. Mādhava's summary of these arguments in his Sarva-Darśana-Sangraha (1981, 243-45).

${ }^{40}$ Bhattacharyya argues that the Mīmāṃsa is not essentially atheistic, but rather rejects the specific reasons and line of arguments - the syllogistic logic — of the Nyāya-Vaiśeșika for establishing God's existence (1961, 30-31). Hiriyanna, however, indicates that the Mīmāṃsaka account for the ordinary changes or dayto-day evolutions "by the self-evolvent character of reality" $(1932,323)$. See also Chemparathy 1972, 150, who points out that by Udayana's time a group of Mīmāṃsakas had reached a compromise with NyāyaVaiśeșika, accepting a subordinate role for Îśvara in re-issuing the Veda in each new cycle, but dependent on the Veda of the previous cycle.

${ }^{41}$ Found in the second section or "bouquet" of Udayana's Kusumāñali.

${ }^{42}$ Cf. the summary of these arguments against the Mimamạsakas in Potter and Bhattacharya 1977, 572-74. 
${ }^{43}$ Goel provides a quick overview of the major Nyāya-Vaiśeșika arguments for the oneness of God (1984, 159-60). The main arguments stress that the unity and harmony of the universe could not have been created by multiple gods, as they would have conflicting purposes, and if they work together, then they must be directed by a single supervisor who makes the role of the others unnecessary. Further, the moral law requires just one overseer of cosmic justice.

${ }^{44}$ Rāmānuja makes the same arguments in his Gītā Bhāṣya 7.12-14 (regarding play); 9.9 (regarding the role of karma in creating inequality). In the latter instance, Rāmānuja cites the Vedānta Sūtras (2.1.34-35).

${ }^{45}$ Smart has a brief summary of Rāmānuja's objections to the design argument, listing nine basic points, along with possible Nyāya-Vaiśeșika rejoinders (1964, 154-56).

${ }^{46}$ I have rearranged the order of Rāmānuja's presentation of the opponent's views and his own, as he frequently weaves back and forth between the two, and includes on one side or the other several associated but distinct arguments all grouped together. For simplicity's sake, I have separated out the distinct arguments, and presented them in a thematic order.

${ }^{47}$ Cf. Smart 1964, 155.

${ }^{48}$ See, for instance, Śrī Bhāṣya 2.1.32-33, as well as Gïtā Bhāṣya 7.12-14 noted earlier.

${ }^{49}$ Debendranath's ambivalence towards science and logical argumentation can be seen in his Brahmo Dharma (1848), in which he also creates a hierarchy between lower sciences like astronomy and geology (and philosopohy!) and the higher science of God. Such a hierarchy influenced Keshab and was to become a key piece in later Hindu disparagements of Darwinism. Keshab's concerns over notions of design and a deistic interpretation of God can be found in various of his writings and speeches, such as his 1866 lecture, "Great Men."

${ }^{50}$ Dayananda's views are succinctly presented in his debate with a Christian missionary at a "fair of religions" held in 1877. For an account of the debate, see Bawa Chajju Singh 1903, 272-313. See also Dayananda 1970, 210-13.

${ }^{51}$ Dayananda's views are well represented by his follower Lala Har Narain, who argues that if we accept Darwinism, "we would be at a loss to trace the origin of human language and the possession of Divine knowledge, which are peculiar to mankind only, and which... are not self-acquired, but can only be learnt from others" (quoted by Singh 1903, 377-78, note). 
${ }^{52}$ I discuss Keshub's notion of Avataric Evolutionism and its probably roots in the writings of Madame Blavatsky in Brown 2007, 431-44.

${ }^{53}$ See, for instance, Ramatirtha 1930-1932, 2:301: "God has no purpose that would mean imperfection [sic]." Cf. Ramatirtha 1930-1932, 2:317, where he writes on the "Design Argument Exploded," observing that "If God acts for a designed end," he must lack something he desires. 